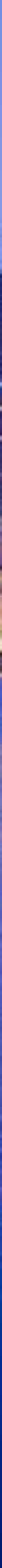




\section{Australia and the Australian people}

The demography, history and culture of the Australian people have been shaped by Australia's size, geographical remoteness, ancient soils and landscape, arid climate, flora and fauna, and bountiful mineral and energy resources. These influences are the result of a rich, and in some ways, unique geological heritage-making Australia a truly 'lucky country'. Australians today number more than 22 million people; we are a diverse nation, having originated from more than 200 other countries. We are custodians of 27.45 million $\mathrm{km}^{2}$ of Earth, including the continent's mainland and offshore extensions, numerous offshore territories, marine zones and a large part of Antarctica.

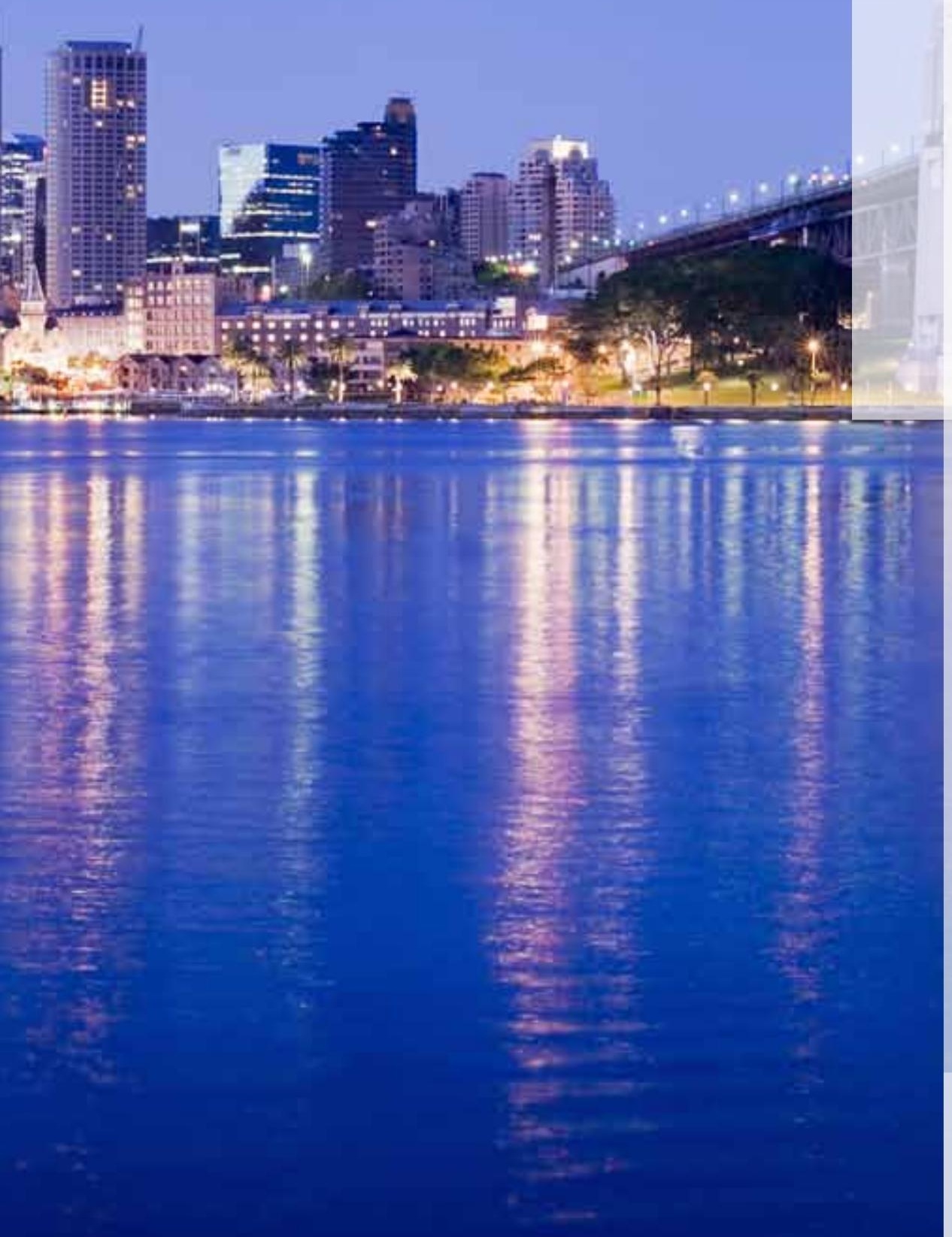

Richard S Blewett, ${ }^{1}$ Phil A Symonds ${ }^{1}$ and Brian LN Kennett ${ }^{2}$

${ }^{1}$ Geoscience Australia; ${ }^{2}$ Australian National University 


\section{O THE LAND THAT SHAPED THE PEOPLE $\left(\right.$ (воx $_{1.1)}$}

\section{Heart of Auss}

I've seen the Rock at the break of day And it seems so right for a place to stay A place in Law to live love and pass away For the people of my Dreaming

That road to Rock bin bitumen-all-da-way But worth the wait when you stay See shards of light that cut bend break and shape The heart of the land of The People

Long time ago there was nothing else No plane no car no photocells

And we walk and we talk and believe the land And bond together in little bands

Then came the pale one and he took stock Will we paint it will we sell it It is Our rock to do to have to colour blue And the people felt old life was through

Now we all live together in this big land and most of our country is covered with sand But there in the centre there stands our heart a sacred place to make a stand

A solid multi-hued rock of our new start And our heart in the land of the people.

John Michael Wenitong (2010)

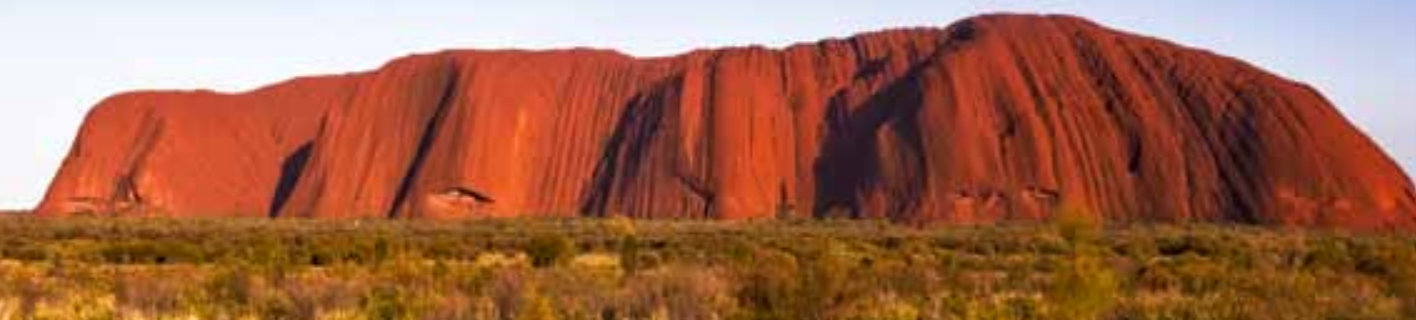

\section{My Country}

The love of field and coppice,

Of green and shaded lanes.

Of ordered woods and gardens

Is running in your veins,

Strong love of grey-blue distance

Brown streams and soft dim skies

I know but cannot share it,

My love is otherwise.

I love a sunburnt country,

A land of sweeping plains,

Of ragged mountain ranges,

Of droughts and flooding rains.

I love her far horizons,

I love her jewel-sea,

Her beauty and her terror -

The wide brown land for me!

An opal-hearted country,

A wilful, lavish land -

All you who have not loved her,

You will not understand -

Though earth holds many splendours,

Wherever I may die,

I know to what brown country

My homing thoughts will fly.

First two and last stanzas, by Dorothea Mackellar (1904)

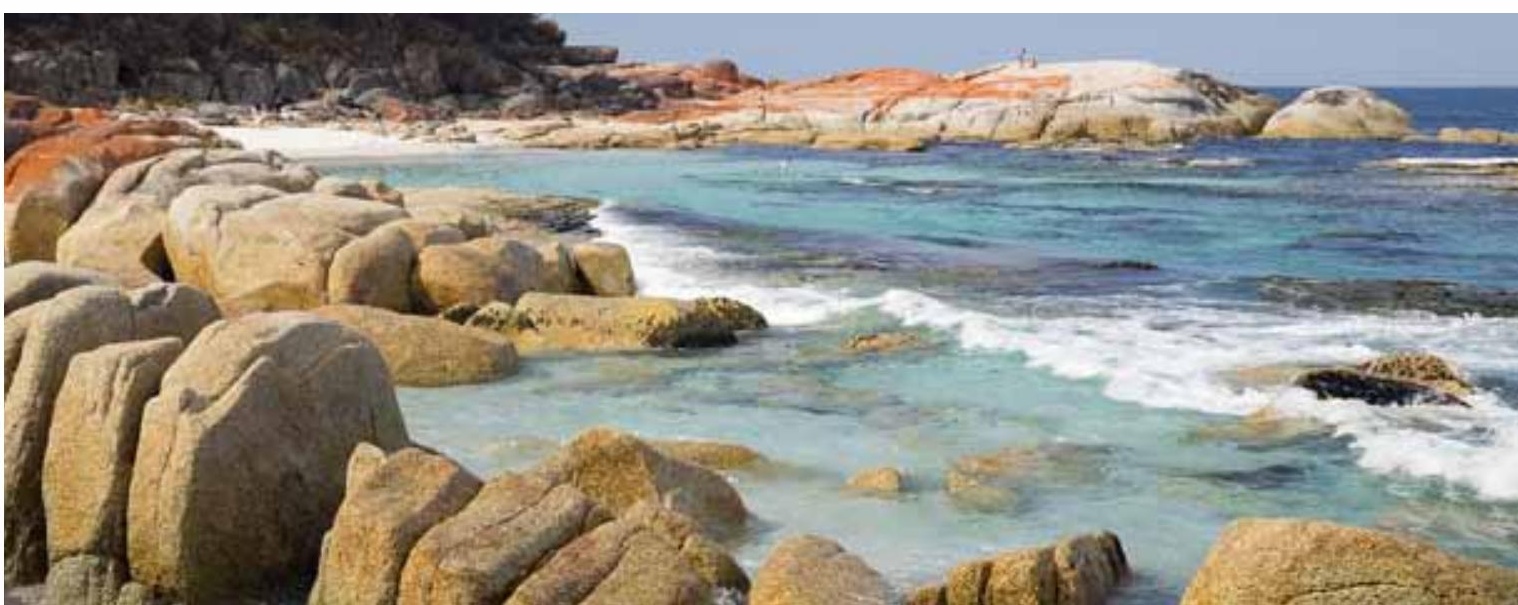




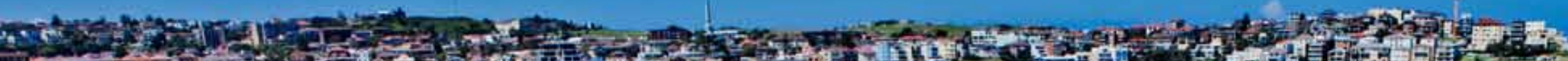

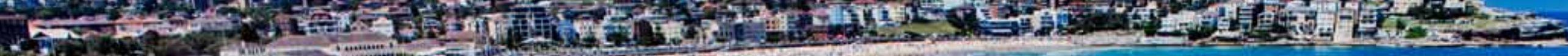

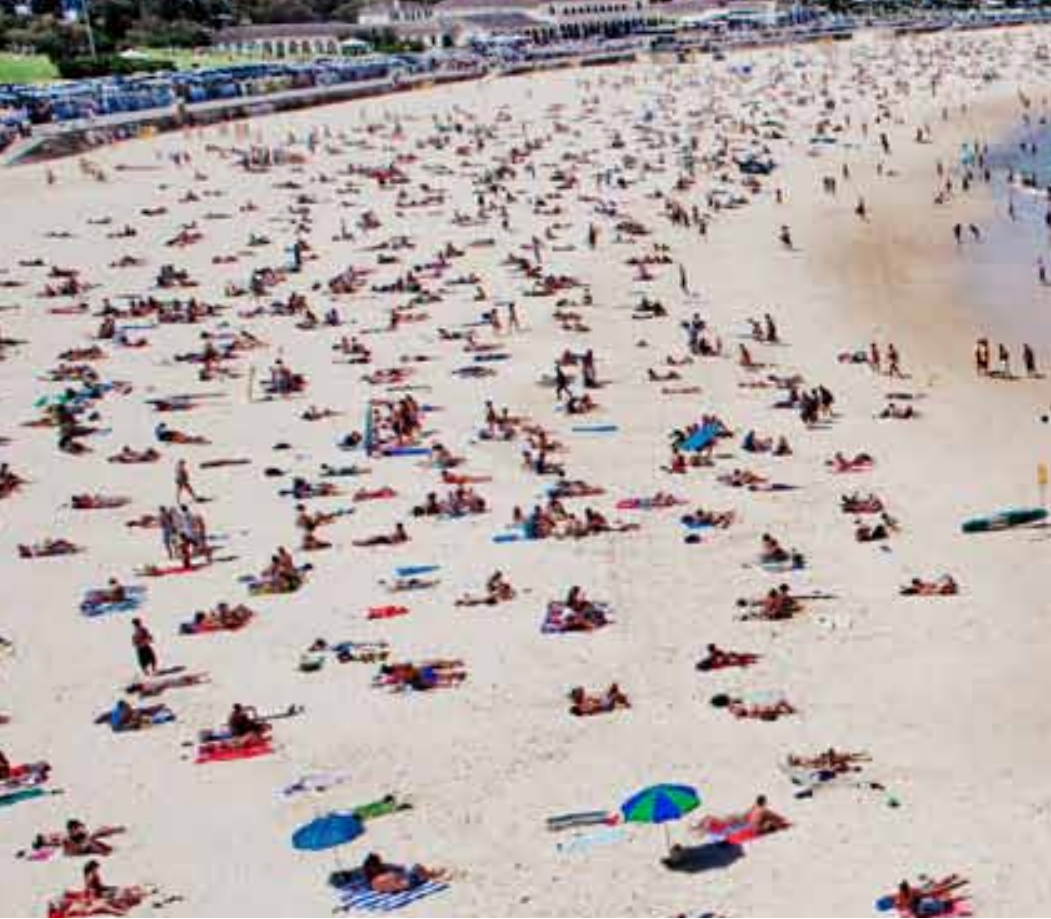

\section{A sense of place}

The land of Australia features strongly in the visual art, poetry and songs of the people. This is especially true for the first Australians- the Aboriginal and Torres Strait Islander people-who have a deep connection with the country; the poem of one Indigenous Australian (JM Wenitong) on the most iconic geological and cultural place, Uluru, epitomises this special connection (Box 1.1). To the first Australians, the word 'country' does not mean just landscape in the usual sense of the rivers, creeks, rocks, hills and waterholes. Rather, it includes all living things; it embraces the seasons, the stories and the creation spirits from the Dreamtime.

More recent arrivals also feel a deep connection to the land. Dorothea Mackellar's homesick elegy, written in London in the early 1900s, conjures vivid images of her adopted land, so different from her English roots (Box 1.1). When Tourism Australia asked what makes this country a special place to live in or to visit, Australians identified the wildlife, beaches, coral reefs, outback, vibrant cities, multicultural people and laid-back lifestyle. By listing these special qualities, and probably without realising it, Australians and their guests identified with the continent's remarkable geology.

This book tells the story of Australia's geology through the lens of its shaping influence on the Australian people and their nation. The story charts our landscape, soils and water, unique flora and fauna, and mineral and energy wealth through a series of interconnected 'pillars' that are deeply rooted in time and space to Australia’s geological 'foundations' (Figure 1.1). Without the geological entity-the rocks that form the 


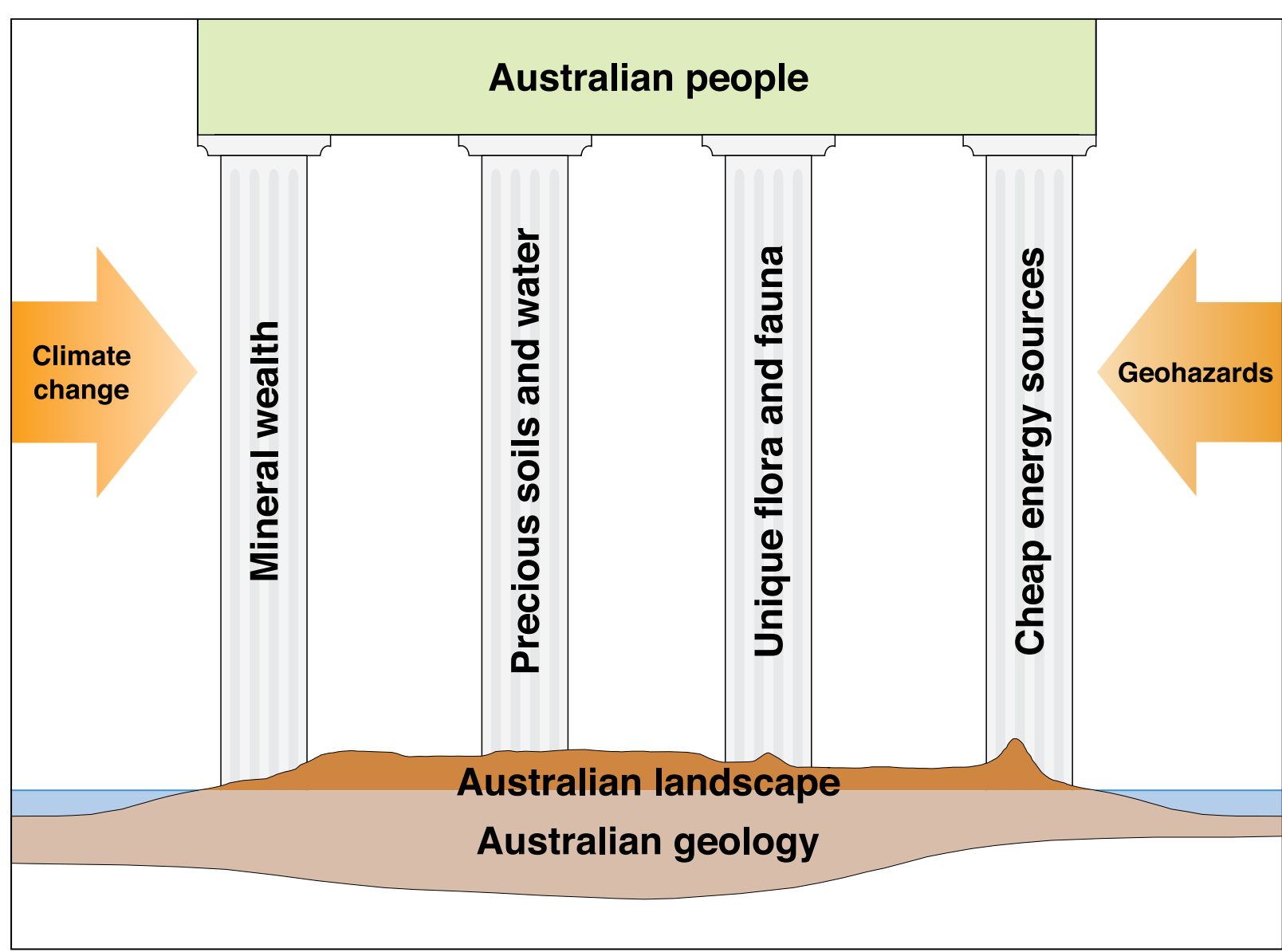

Figure 1.1: Conceptual portrayal of how geology shapes the Australian people. We exist only by 'geological consent' (Durant, 1926). Geology forms the foundation of the landscape within which the soils and water, unique flora and fauna, mineral wealth and energy sources have evolved. These are the rocky 'pillars' that support society, and that climate change and geohazards sometimes undermine.
Australian continent-we would not have such an exciting story to tell. First of all, we give you what makes Australia today. The geological process of continental drift has placed the island continent of Australia into its present climate system south of the equator. This southern climatic regime has acted on ancient geological roots to create a distinctive Australian landscape. The landscape has also been shaped in time by water and soils, which are now scarce and fragile. Australia has evolved unique flora and fauna, and into this environmental system people arrived, possibly as long ago as 60000 years. Australia's geology also endows the continent with an abundance of mineral and energy resources, first sustaining the people and then making the nation wealthy. Civilisation and the choices made, however, only exist with the 'consent of geology', with geohazards and climate change providing challenges and constraints for the Australian people. Fortunately, this 'lucky country' has provided its citizens with numerous choices for the future.

Let us look closer at the Australian people and their nation.

\section{The Australian people}

The Aboriginal and Torres Strait Islander people, the traditional owners, are the first Australians. They arrived from the north up to an estimated 50000 to 60000 years ago (ka), via sea and land bridges moulded by climate change, into a country that was very different from today. In terms of the migrations of Homo sapiens, the ancestors of today's Indigenous people travelled the furthest and fastest of all the migratory people out of Africa. At sea-levels $60 \mathrm{~m}$ below those of today, Australia, New Guinea and Tasmania (Tas.) formed a single continent called Sahul (Figure 1.2). Even at the glacial maximum when sea-level was about $125 \mathrm{~m}$ lower than today, this landmass was never connected to the Asian mainland, so island hopping from Sunda across Wallacea to Sahul required several open-ocean crossings, some more than $80 \mathrm{~km}$ (Figure 1.2).

Today, Australians originate from a rich variety of cultural, ethnic, linguistic and religious backgrounds. Other than the first Australians, 
the more than 22.7 million (M) people who call themselves Australians are immigrants, whose ancestors and descendants arrived during the past two centuries from more than 200 countries. Most have come from lands radically unlike Australialands with regular and predictable seasons, with flowing rivers and lush fertile plains, not a land with deserts, 'droughts and flooding rains' (Box 1.1).

The Bugis people from Macassar in Sulawesi (Figure 1.2) knew of Australia long before European or North Asian people. They collected bêche-de-mer (trepang) on the northern coast, but did not settle, returning to their apparently more favourable homelands. The first European contact with Australia occurred mostly along the harsh western and northern coast by sailors-Portuguese, Dutch, British, French-intent on reaching the Spice Islands of Indonesia. Ironically, they sailed past or above the mineral and energy riches of the northwest (Chapter 9). The land was regarded as best avoided, with little to offer. Past climate was not always as harsh as it is today (Chapter 5). The interior deserts and the tropical north, largely shunned by Europeans, have been productive regions for Aboriginal people. Linguistic maps illustrate that most of Australia was occupied and, in contrast to European perceptions of the land, these areas gave a good living to the modest numbers of Aboriginal people.

Only much later was the more temperate and fertile east coast of Australia mapped by Captain James Cook. The 18th century British claim of sovereignty was unique in history, as it claimed a continent for a nation and a nation for a continent. Until the advent of long-distance aircraft, all

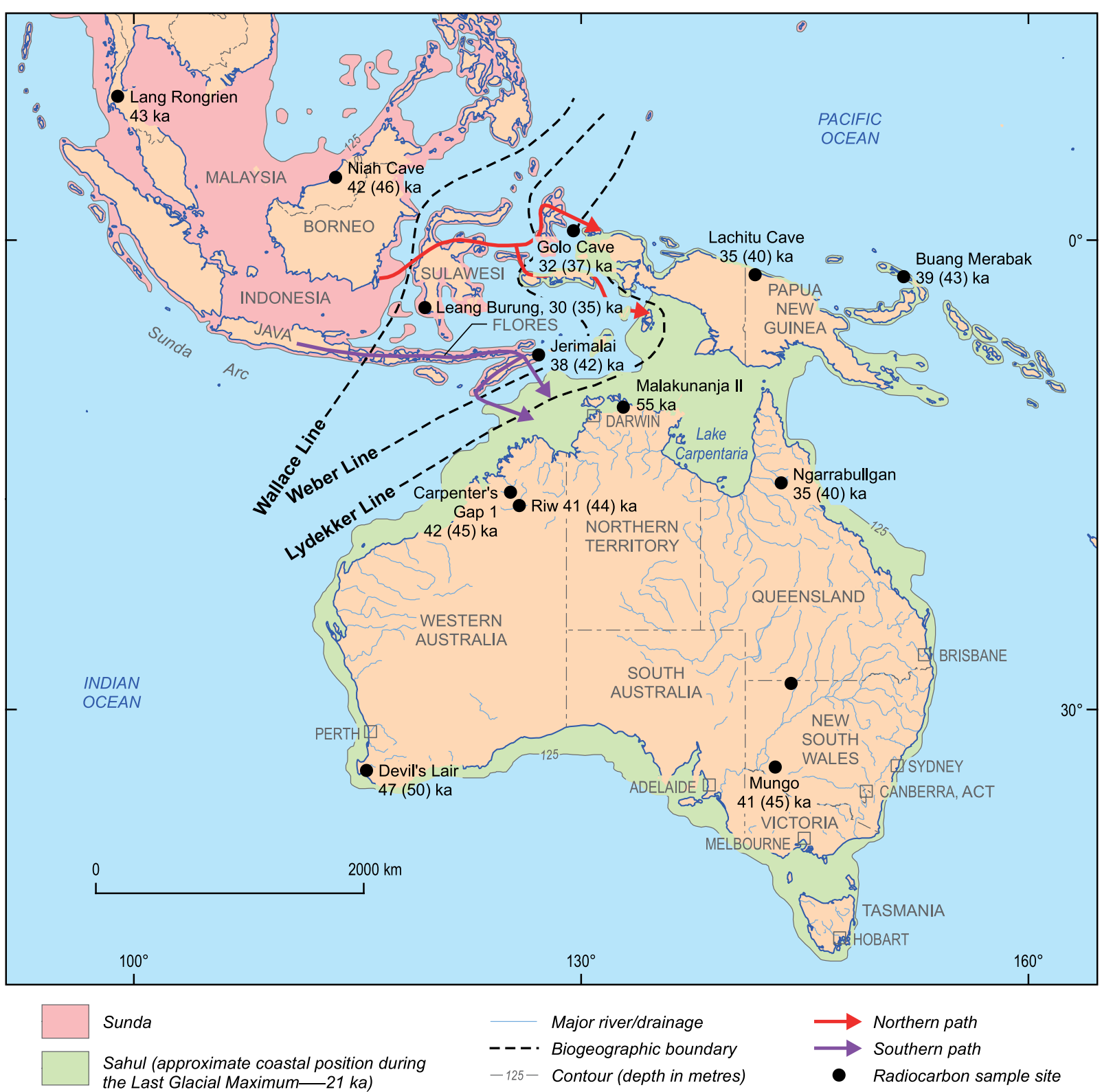

Figure 1.2: Approximate render of dry land with sea-level $125 \mathrm{~m}$ lower than today, showing the outline of Sunda, Sahul and intervening Wallacea. Human arrival into Australia may have taken a northern or a southern path, both necessitating ocean-going vessels. Once humans entered Australia, they were able to travel as far south as Tasmania. The oldest archaeological sites in Sahul are shown with radiocarbon dates as uncalibrated (raw) ages. (Source: after O'Connor, 2009) 
newcomers arrived by sea. Coastal geography and

the availability of reliable potable water were key factors in determining early settlement patterns. The capital cities of each state were founded as ports, with maritime trade critical for their individual development and the nation as a whole (Chapter 6). Despite this, there is not a strong maritime tradition in Australia. For example, the modern-day so-called grey nomads circumnavigate Australia not by yacht, but with a four-wheel drive and caravan. People as diverse as artists and adventurers looked inwards, despite the isolating influence of the surrounding seas that so shaped the history of Australia.

Historically, Aboriginal people are from mainland Australia and Tasmania. Torres Strait Islander people come from the islands between the tip of Queensland (Qld) and New Guinea and share many cultural similarities with the people of New Guinea and other south Pacific islands. Australian Indigenous culture is diverse and is the longest continuous living culture on Earth. Since the late 20th century, this culture has been increasingly recognised as an integral and sustaining core to Australia's national identity.

It is estimated that there were between 300000 and 750000 Aboriginal and Torres Strait Islander people in Australia at the start of European settlement in 1788. This population declined dramatically during the 19 th to mid-20th centuries due to factors including conflict on the frontier of European settlement, the impact of new diseases and other social problems.

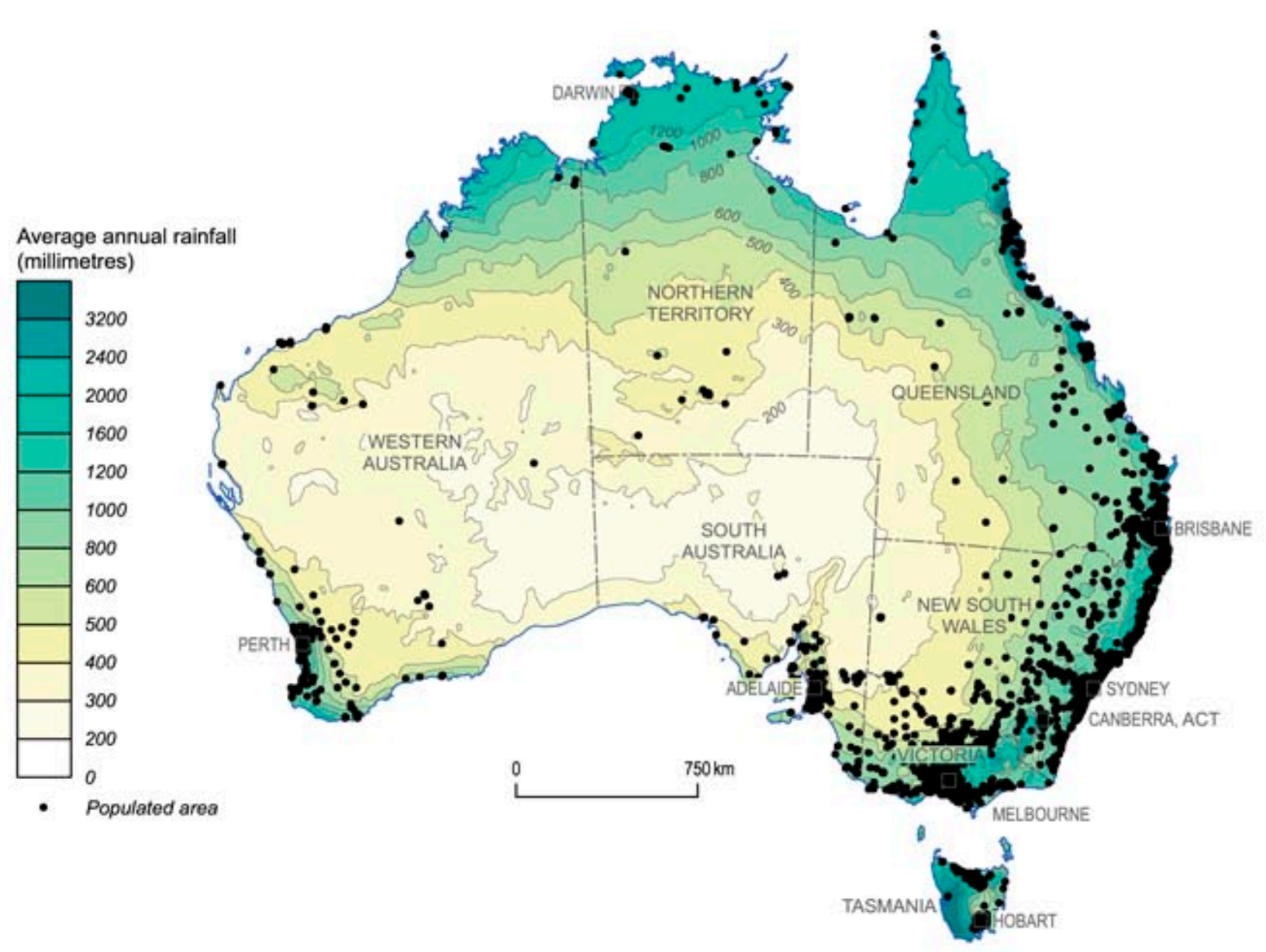

Modern immigration began with the British First Fleet in 1788 , and continued at a steady pace until the discovery of gold in 1851 (Box 1.2). The population growth rate then jumped to 50000 immigrants per year during the subsequent gold rushes of the 1850 s, with new arrivals from many parts of the world. Asian immigration, in particular by Chinese people, commenced at that time (Chapter 8 ). By the 1940 s, the population reached $7 \mathrm{M}$, with the bulk of settlers from a British background. Since World War II, more than 6.6 M migrants from more diverse backgrounds have arrived in Australia.
Figure 1.3: Population distribution of Australia, with each dot representing 1000 people. Note the population concentration in the southeast, east and southwest coastal regions of the mainland and around Tasmania, and the scattered and sparse distribution for much of the interior and the north. The boundaries of the states and territories are also delineated. (Source: Australian Bureau of Statistics, 2006. Data are usual residence, mapped to the 2006 Australian standard geographical classification) 


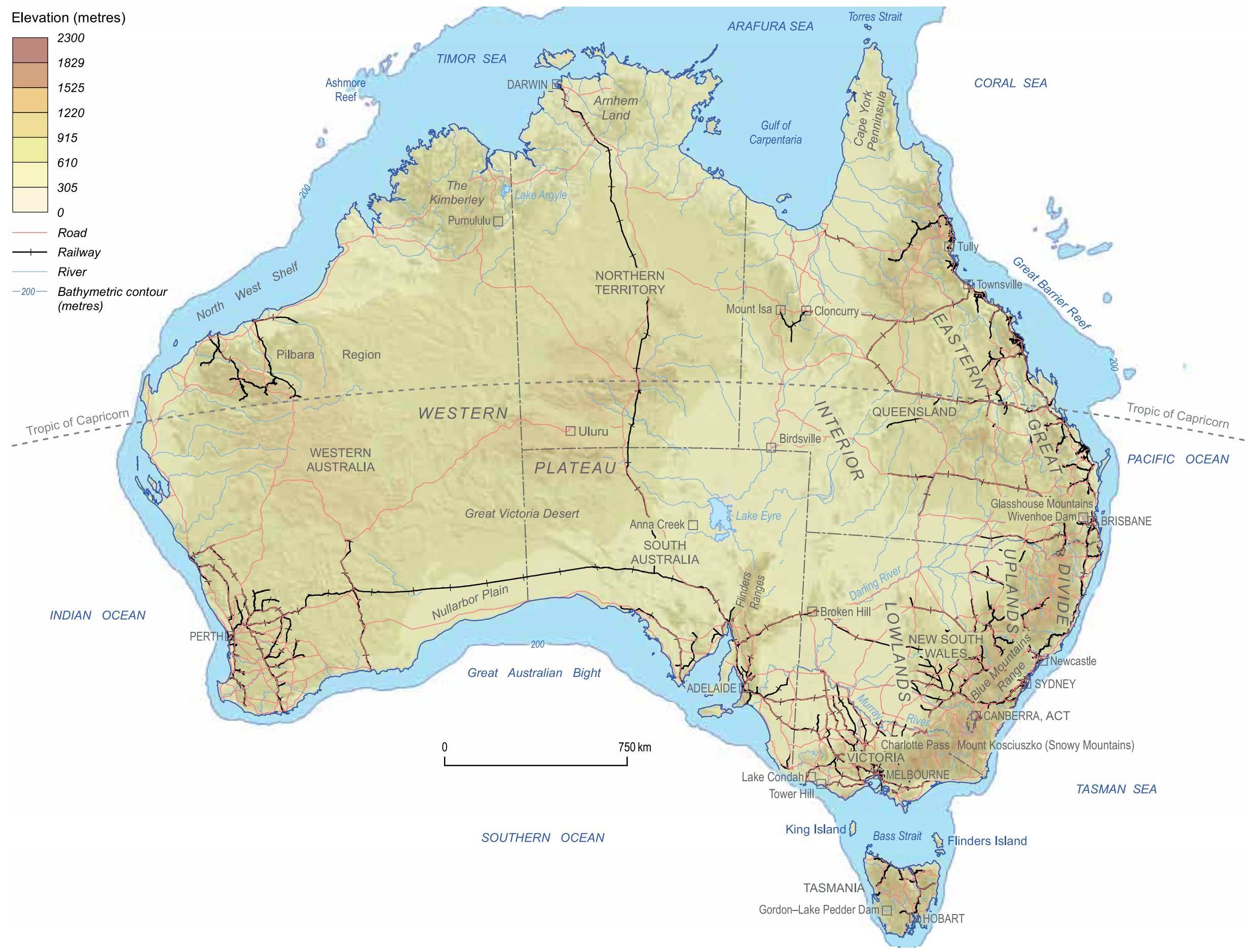

Figure 1.4: Prominent geographical features of mainland Australia, showing major rivers and deserts, population centres and major transport links. Note the remoteness of the centre and its lack of roads or settlement. The boundaries of the states and territories are also delineated. The distance from the coast of the $200 \mathrm{~m}$ bathymetric contour varies widely. 


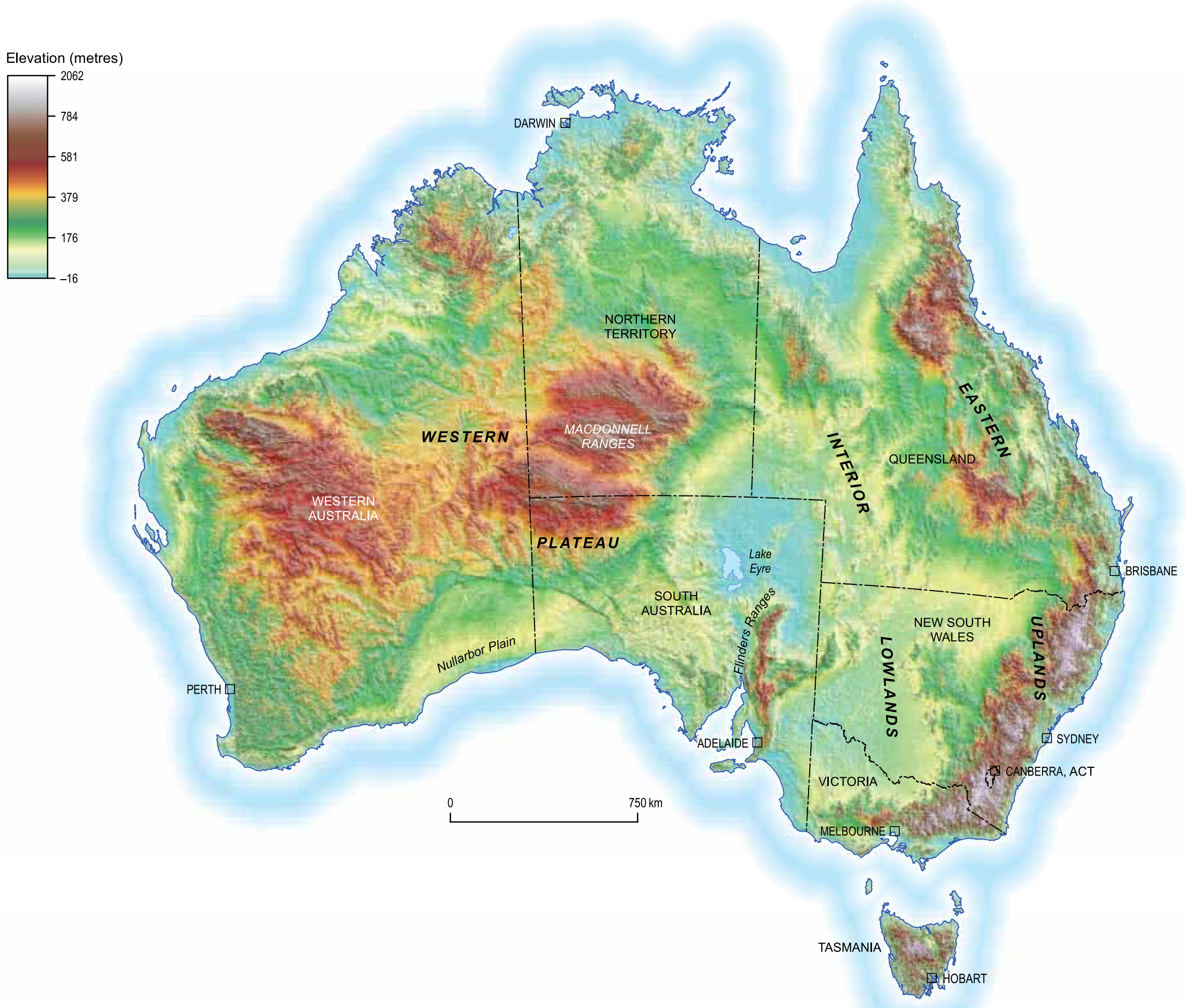

Figure 1.5: Digital elevation model of Australia, showing the main physiographic features of the continent. 
Australia has a land area of $7.69 \mathrm{M} \mathrm{km}^{2}$, making it both the largest island and the smallest continent. The coastal outline is distinctive and recognisable and stretches more than $3860 \mathrm{~km}$ from north to south and almost $4000 \mathrm{~km}$ from east to west. This east-west distance is comparable to that between New York and San Francisco in the United States, Lisbon and Moscow in Europe, and Beijing and New Delhi in Asia.

In area, mainland Australia is the sixth largest nation after Russia, Canada, China, the United States and Brazil (Figure B1.3). Australia has about twice the area of the European Union or the Association of Southeast Asian Nations (ASEAN). Australia's marine jurisdiction-in the top three in the world, along with the United States and France-lies in three oceans and covers nearly $12 \mathrm{M} \mathrm{km}^{2}$.
In fact, Australia is custodian of about $3.8 \%$ of the oceans, and about $9.1 \%$ of the land, with a full land and marine jurisdiction of $27.45 \mathrm{M} \mathrm{km}^{2}$ (Table 1.1). Within its exclusive economic zone, Australia has certain sovereign rights to the natural resources (living and non-living) of the water column, seabed and subsoil in areas adjacent to Australia's territorial seas and jurisdiction over the water column, seabed and subsoil.

Australia has a number of large islands in the Pacific, Indian and Southern oceans and the Coral and Timor seas as part of its external territories, as well as several closer to the mainland that are larger than $1000 \mathrm{~km}^{2}$. Tasmania, with its distinctive heart shape, is Australia's largest island, with an area of $64519 \mathrm{~km}^{2}$ and an additional $3882 \mathrm{~km}^{2}$ of fringing islands. Islands are important for determining the size of a nation's exclusive economic zone. The small Heard and McDonald islands, for example, add some $410722 \mathrm{~km}^{2}$ to Australia's exclusive economic zone.

For an island nation, coastlines play an important role in defining national, state and territory boundaries. For example, the 260 or so inhabitants of the low-lying Boigu Island in Torres Strait live only 4 km from Papua New Guinea, our nearest neighbour.

Calculations for Australia's coastline lengths are taken from Geoscience Australia's GEODATA Coast 100K 2004 database. The length of the Australian coastline is $59736 \mathrm{~km}$, comprising a mainland of $35877 \mathrm{~km}$ and fringing islands of $23859 \mathrm{~km}$.
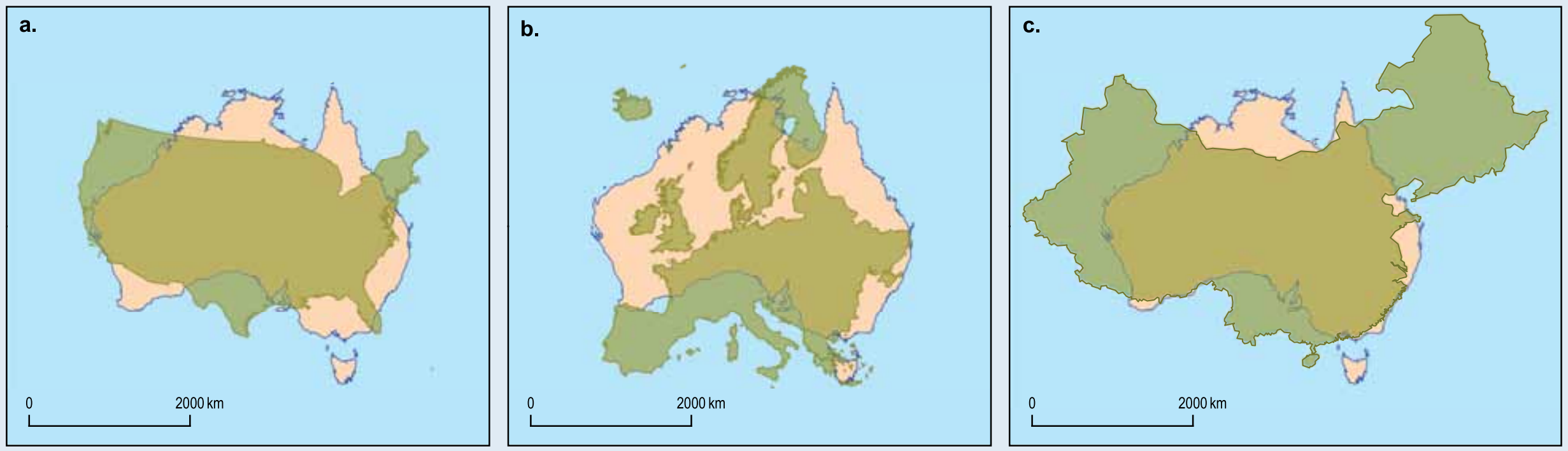

Figure B1.3: Comparative size of continental Australia (population 22.7 M) with: (a) the conterminous United States of America (population $>300 \mathrm{M}$ ), (b) Western Europe (population $>500 \mathrm{M}$ ) and (c) China (population $>1.3 \mathrm{~B}$ ). 
Road trains ply the long and dusty outback roads of Australia, carrying goods and livestock to and from remote communities and their markets. of more than 80000 people, accommodate another $14 \%$ or so. Even the exploitation of mineral and energy resources in Australia's outback has not changed this pattern; instead, many workers fly-in/fly-out (FIFO) to the remote locations from their urban home base (Chapter 9).

Australias low population density, the vast distances between settlements (Box 1.3) and the availability of land have all shaped the nation in many ways.

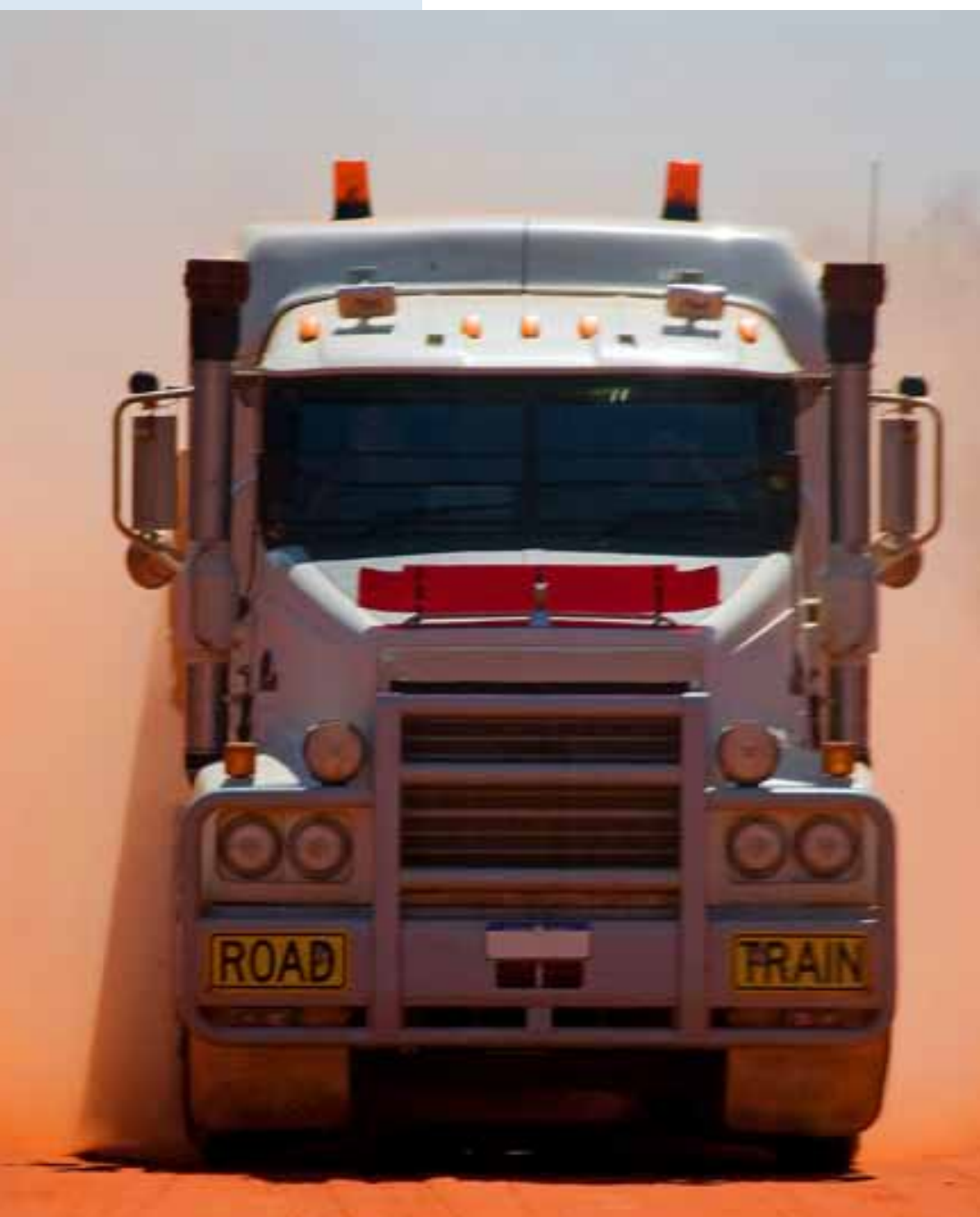

O Getty Images IJ Clutterbuck

The 'quarter-acre block' typified the post-World War II population and construction boom. This expansion was facilitated by the availability of abundant land and cheap energy, which allowed towns and cities to sprawl into the countryside, some of which is Australia's most productive for agriculture (Chapter 10). In the more remote areas, landowners can control enormous parcels of land. Anna Creek Station in South Australia (SA), for example, runs cattle and is the world's largest individual property holding at $34000 \mathrm{~km}^{2}$. Graziers on these large properties typically use helicopters for mustering (rounding up) their cattle. Gone are the stock routes and cattle drovers of the late 19th to mid-20th centuries (Chapter 7). Instead, there are now 'road trains', some up to 200 tonnes $(\mathrm{t})$ and consisting of three or four linked trailers.

The distances in Australia are large; they are measured in days of driving. Football fans have been known to drive the $900 \mathrm{~km}$ from Mt Isa to Townsville to watch a rugby league match. Shopping can be $200 \mathrm{~km}$ away from home. The low population density means that there is a small tax base to pay for quality highways in such a vast continent. It was not until 1988 that Australia completed the bitumen of the road network encircling the country. The regolith (surface material) cover over much of Australia's inland is of poor quality for use in road building (Chapter 5). The surface readily breaks down, the roads become corrugated, and in places deep, fine-grained 'bull dust' holes develop. The great distances and scattered remote populations in the outback fostered the Royal Flying Doctor Service (established in 1928), whose motto, 'the 
furthest corner-the finest care', ensures that all Australians are afforded the benefits of 'medivac' access to modern medicine.

Only in the last few years, as global communication has become almost instantaneous, has the sense of remoteness been challenged, although even now the time-zone differences to Europe and North America can prove difficult. The coming of the Internet has revolutionised outback living, with everything now more accessible, from Schools of the Air to checking weather reports of floods and cyclones to sourcing replacement parts, facilitating direct communication for business and citizens. Today, Australia's major trading partners lie to the north, with China, Japan and India being only a time difference of a couple of hours away.

From its foundation as a European-oriented enclave many weeks by sea from the homelands, Australia was forced to rely on its own resources and initiative as far as possible, although high-cost imports were also needed, and paid for by wool and mineral wealth. Local ingenuity was applied to many specific problems, and clever solutions were found without external input. A classic example is the 'stump-jump' plough, invented by Richard Smith in 1876 to counteract the roots of trees left in the ground after clearing of the native vegetation. Even today, items such as the rotary Hills hoist for drying washed clothes in quarter-acre suburban backyards (Chapter 10) are part of the Australian vernacular and seem strange to newcomers.

Less visible is the significant innovative contribution made by the mining technology and services industry. The perfection of the flotation method at Broken Hill in the early 1900s, for the recovery of non-ferrous metals, was a major technological achievement. Prior to this, zinc $(\mathrm{Zn})$ recovery at Broken Hill was only $12 \%$, and recovery of silver $(\mathrm{Ag})$ and lead $(\mathrm{Pb})$ was $50 \%$ and $70 \%$, respectively. The evolution of the technique was led by Guillaume Delprat, the General Manager of BHP from 1901, and benefited from the skills of Auguste de Bavay, a Belgian brewer for Fosters beer. This somewhat counterintuitive process selectively floats different sulfide minerals. This technology is seen as the genesis of modern mining, leading to the development of Australia's manufacturing industry. During post-World War II construction of the tunnels for the Snowy Mountains hydroelectric and irrigation scheme (Chapter 5), Australian engineers invented the expanding rock bolt, which allowed that project to proceed quickly and safely. This invention revolutionised underground mining and tunnelling across the world. More recently, Australian innovation in computer software for mining and exploration accounts for around 60\% of the global market. This industry generates more export earnings for the nation than the more widely known wine industry.

Australians are proud of their harmonious multicultural society. This developed in part through hardship and necessity, governed by a small population in a large country with many opportunities, with people distant from homelands. The new land, both physically and socially, contrasts greatly with where many settlers originated. The Australian culture and democracy are exemplified by a sense of a 'fair go' (justice for all)

\section{Did knơw?}

\section{1: Australian Coat of Arms}

Australian native species feature in national symbols. The supporters on either side of the Australian Coat of Arms, for example, are the red kangaroo (Macropus rufus) and the emu (Dromaius novaehollandiae). The kangaroo and emu were chosen to symbolise a nation moving forward, reflecting a common belief that neither animal can easily move backwards.

The arms is depicted on a background of sprays of golden wattle (Acacia pycnantha), which was proclaimed Australia's national flower in the bicentennial year 1988.

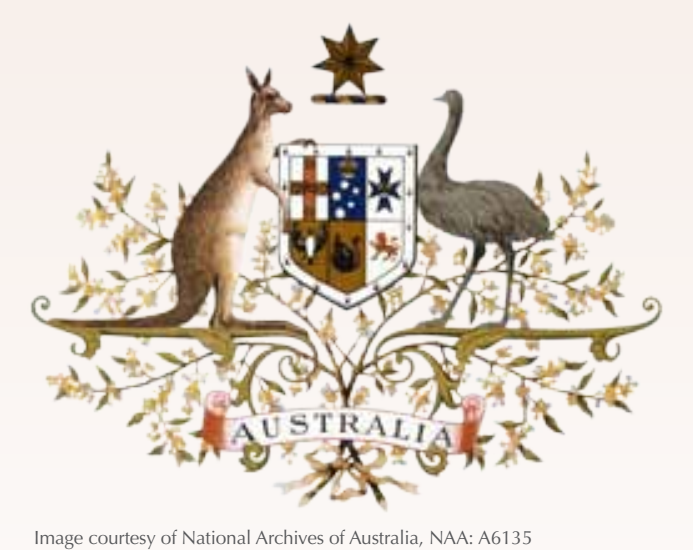


and egalitarian spirit. Few people in a big country meant that labour shortages occurred, driving up wages and enhancing workers' conditions, such as an eight-hour day and weekends free from work. These factors also facilitated the early development of trade unions and universal suffrage. Increased leisure time and money, together with Australia's favourable climate and available space, led to a strong sporting culture and a fierce rivalry with the 'mother country' (e.g. Ashes cricket test matches against England). Sport is an Australian passion, and many of the national sporting teams have faunal names, or their derivatives, such as the Wallabies, Kangaroos, Kookaburras and 'Socceroos'.

A consequence of Australia's small population density is the low number of people available to explore and understand the continent. The fundamental geographical attributes of Australia are the product of the geology - in particular, its continental position, which has influenced the past and present climatic belts, the water balance and flow, the landscape, soil fertility, and the unique flora and fauna. All of this has combined to create the unique continent called Australia, thus shaping the people who live here-the Australians.

Having met the Australian people, let us now consider the role that geology has played in shaping their past and the likely influences on their future.

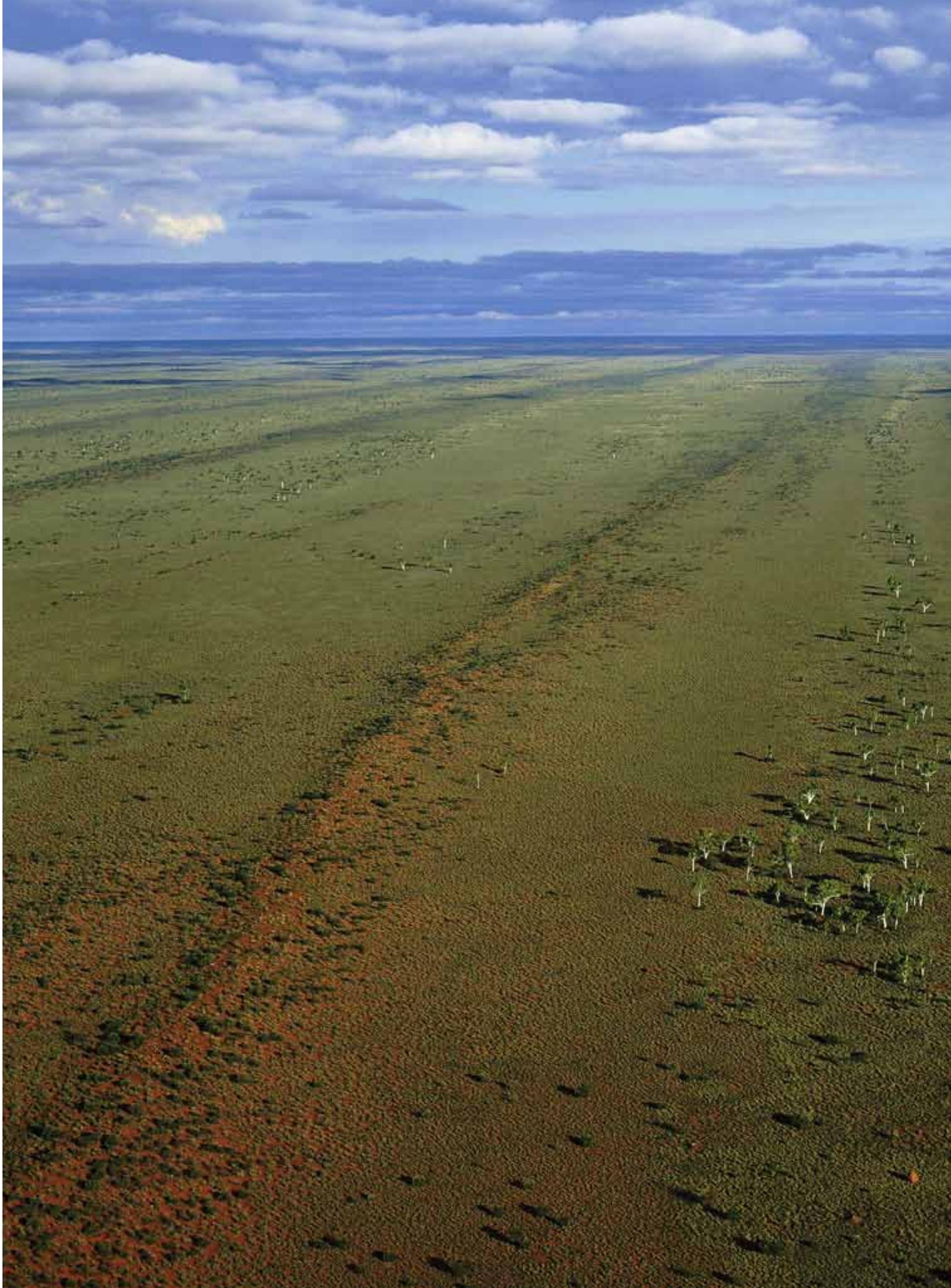




\section{Australian geology: the foundation that shapes the people}

This book is not another 'geology of Australia' with the rocks, minerals and fossils catalogued through time. We wanted instead to concentrate on the geological processes that made this great continent and in turn show how the underlying geology has shaped many aspects of our nation and society (Figure 1.1).

Australia's defining moment occurred around $34 \mathrm{Ma}$ when the continent finally rifted from Gondwana (Antarctica). This geological event set in motion the primary shaping influences on the modern Australian continent. It led to the present-day geographical position ('down under') and tectonic setting, both of which have led to the formation of Australia's unique and ancient landscape (Chapter 5).

Australia's separation from Gondwana released the continent from cold high-latitude southern regions, allowing it to drift rapidly northwards. From the Late Miocene ( $c a 10 \mathrm{Ma}$ ) onwards, most of the Australian continent has been positioned where it occurs today, in the horse latitudes (subtropical high) of the Southern Hemisphere, particularly during the warmer months. This simple geographical

- Aerial view of longitudinal sand dunes in the Simpson Desert of central Australia. o Getty Images [P Harrison]

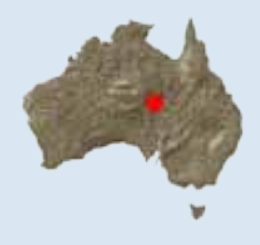


processes are forming ore deposits, so-called 'black smokers', on the seafloor around Papua New Guinea, along the northernmost extension of the Australian Plate (Chapters 2 and 8). Magmatic processes have also enriched certain granites in potassium (K), uranium $(\mathrm{U})$ and thorium $(\mathrm{Th})$ to produce high heat-producing granites that form a potentially vast geothermal resource (Chapter 10).

One of the reasons for the diversity of Australian geology has been complex relationships between stable cratonic elements and intervening orogenic belts. Much of the western two-thirds of Australia consists of cratonic blocks that have been stable since the middle Proterozoic or even the Archean, whereas the eastern third is dominated by a complex orogenic belt associated with the formation of Gondwana and Pangaea (Chapter 2). Most of Australia's mineral (Chapters 8 and 9) and hydrocarbon (Chapter 4) wealth formed as a consequence of the interplay between cratonic and orogenic Australia.

A surprising portion of Australia is covered by Mesozoic basins. In contrast to the older basement terranes, which tend to be hilly or mountainous, these basins can be incredibly flat but contain one of Australia's most important resources, groundwater (Chapter 7). The Great Artesian Basin, which extends from South Australia to northern Queensland, provides the groundwater essential for agriculture, the backbone of the economy of this vast area (Chapter 7).

Some Australian landscapes are very old, perhaps even early Paleozoic in age. Around $80 \%$ of the continent is covered by a veneer of regolithweathered rock, sediments and soils. Australia is a land of geological contrasts that have added variety to our natural history and supported a very diverse economy.

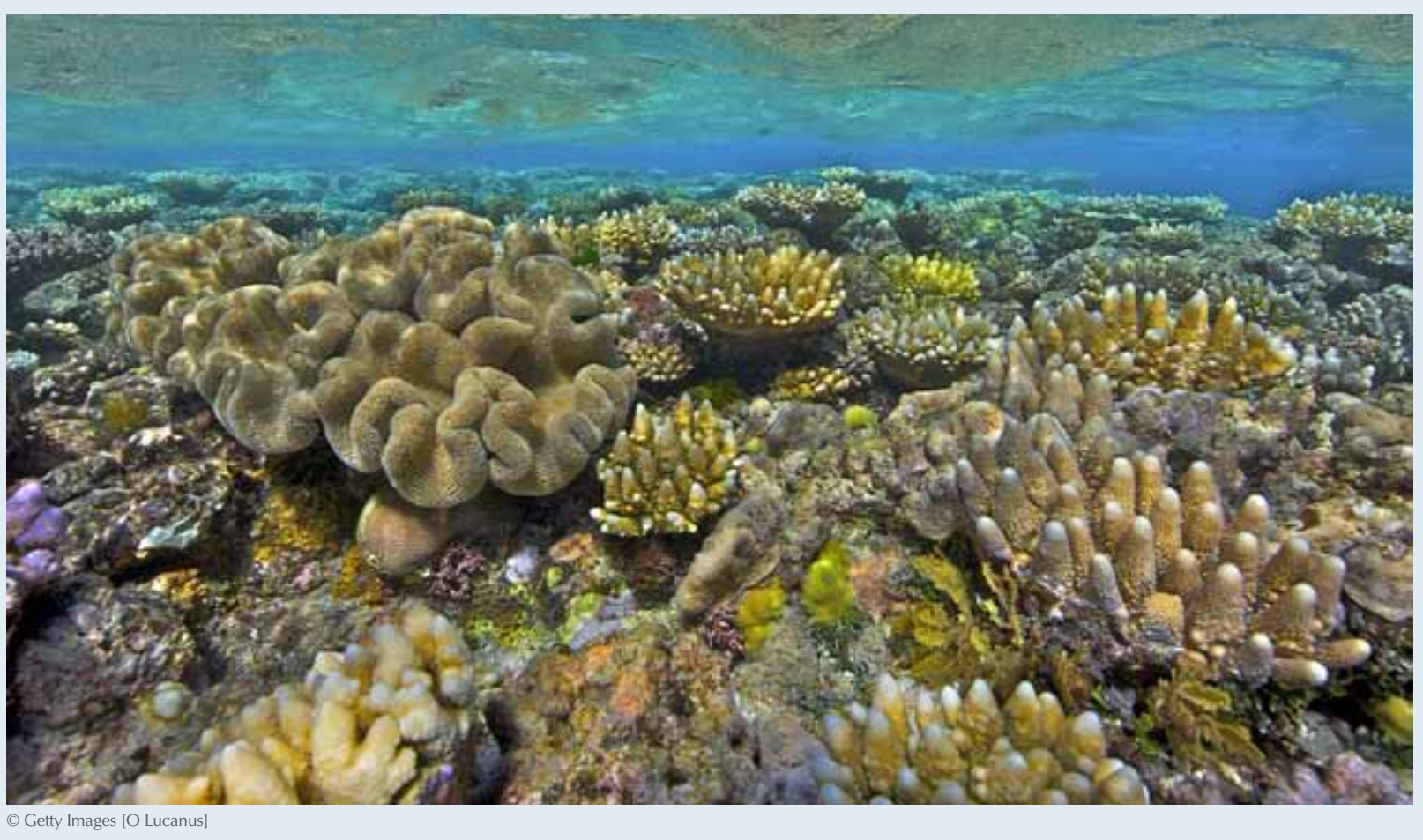

Rock formation before your eyes_-the Great Barrier Reef, Queensland.

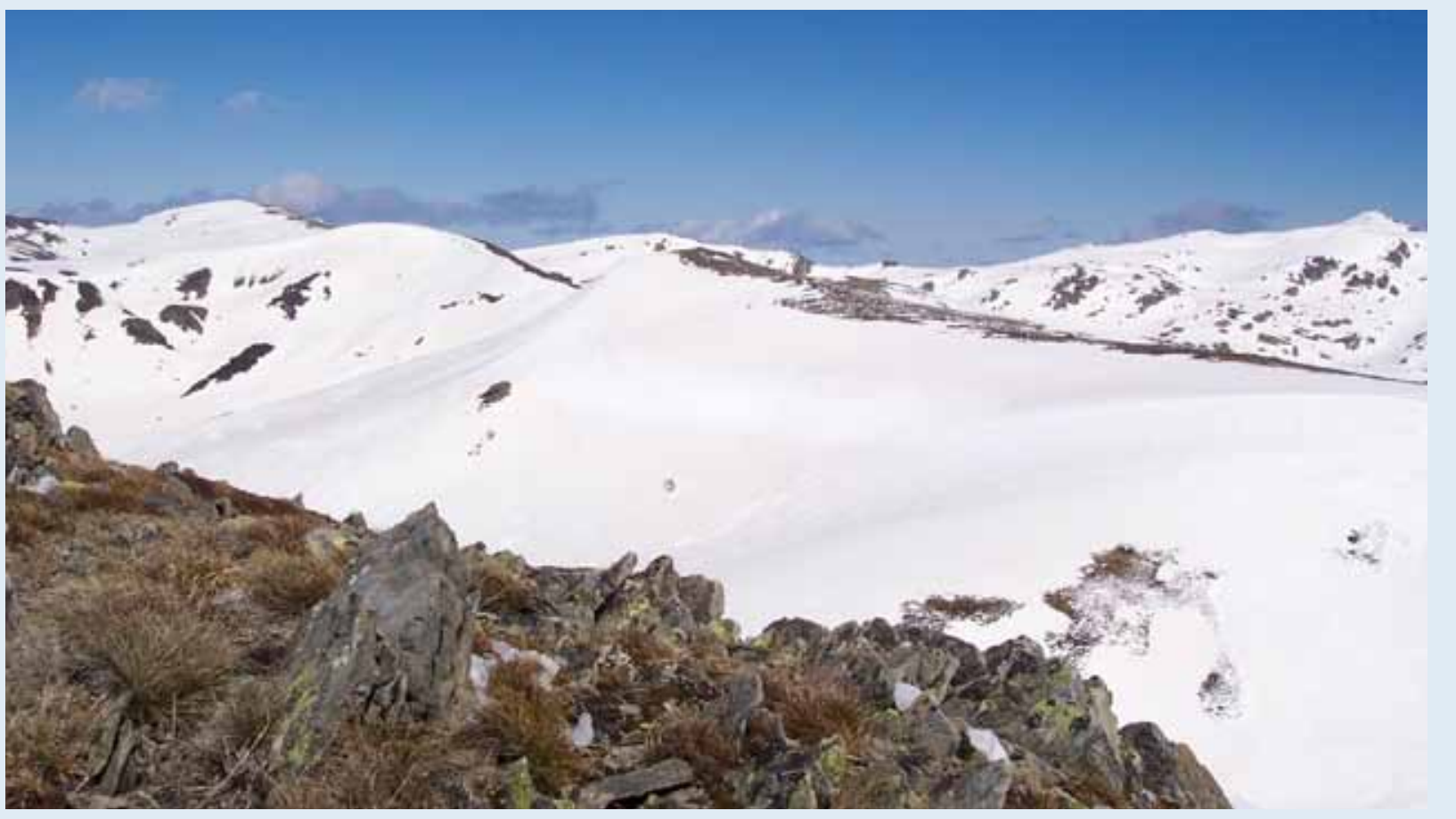

Spring snow on the Main Range, Snowy Mountains, New South Wales. 


\section{Did know?}

\section{2: The SydHarb is a uniquely Australian unit of measurement}

When describing volumes of water, Australian hydrologists tend to talk in megalitres or gigalitres, or even numbers of Olympic-sized swimming pools. They also use the uniquely Australian term, a SydHarb (or Sydharb, Sydarb):

- One kilolitre (kL) is 1000 litres or the volume of a cubic metre.

- One megalitre $(\mathrm{ML})$ is one million litres or the volume of 10 cubic metres

- One gigalitre $(\mathrm{GL})$ is one billion (B) litres or the volume of 100 cubic metres.

- One cubic kilometre $\left(\mathrm{km}^{3}\right)$ contains $1000 \mathrm{GL}$.

- One SydHarb is the amount of water in Sydney Harbour, nominally $562 \mathrm{GL}$.

- One Olympic-sized swimming pool is $50 \mathrm{~m}$ long, $25 \mathrm{~m}$ wide and $2 \mathrm{~m}$ deep, so holds $2500 \mathrm{~m}^{3}$ or $2.5 \mathrm{ML}$.

By way of example, the massive rainfall event on 11 January 2011 resulted in about two SydHarbs flowing into Brisbane's Wivenhoe Dam in 24 hours.

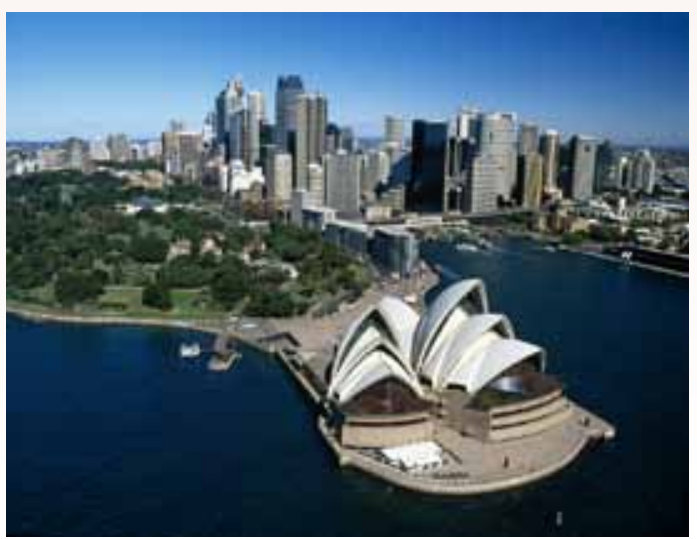

fact means that much of Australia is arid. Due to the low-latitude position, most of the Australian landscape did not receive the rejuvenating benefits from the Quaternary glaciations to the soils that other continents did (Chapter 2).

Australia's rifting out of Gondwana formed passive margins on three sides of the continent (Chapter 4), positioning Australia distant from destructive plate margins. This is a major reason why Australia is the flattest and lowest of all continents. The lack of mountain building events has also limited the rejuvenation of the landscape and is another reason why Australia's landscape is so old and the soils so leached, poor and salt prone (Chapter 5). The flatness has also prevented the formation of major transcontinental river systems, which, together with the lack of rainfall, means that sediment supply into marine basins is very limited (Chapter 6).

The aridity, together with the infertile ancient soils, has shaped the flora and fauna and the carrying capacity of the land for agriculture and people (Chapters 3, 5 and 7). These factors have thus influenced Australia's demography, with most of the population concentrated near the more fertile and temperate coast in the southeast and far southwest of the continent (Figure 1.3).

Australia's distance from destructive plate boundaries means that the threat from geohazards, especially earthquakes, volcanoes and tsunamis, is different from that of Australia's neighbours. Australia's geographical position, however, means that tropical cyclones, droughts and floods, bushfires and heatwaves are common (Chapter 6).
Rocks and minerals in Australia span most of Earth's geological history (Box 1.4), with more than two-thirds of the continent underlain by Precambrian rocks (Chapters 2 and 10). This great span of geological time means that Australia has benefited from numerous geological events that give us both an iconic geoheritage and vast mineral and energy resources. These resources not only shaped how the nation developed (Chapter 8), but today are the backbone of the nation's economy (Chapters 4, 9 and 10).

We shall now look in more detail at how the geological foundation, and the 'pillars' it supports, have shaped our nation (Figure 1.1).

\section{Australian geography: the land down under}

Geology has positioned Australia between the southern trade winds and the northern monsoon belts. This geographical factor has had a profound influence on the continent's climate (Figure 1.6). If Australia were located in the Northern Hemisphere, it would occupy much of the Atlantic Ocean, in a position adjacent to the African Sahara Desert.

With the end of the last ice age, global temperatures increased and sea-levels rose rapidly by $125 \mathrm{~m}$ (Chapter 6). This rise flooded land bridges between Tasmania and the Australian mainland (11 ka), and between Australia and New Guinea (9 ka). The sea-level rise also inundated about one-seventh of the larger ice-age continent (Sahul), isolating Tasmania, the Australian mainland and New Guinea (Figure 1.2). Many smaller islands appeared around the evolving continenta 
landmass as rising sea-level isolated high-standing land (e.g. King and Flinders islands between Victoria and Tasmania). New islands were fashioned as reef-building organisms constructed atolls and cays (e.g. Ashmore Reef on the North West Shelf). The rise in sea-level flooded deep river valleys (rias), creating the likes of Sydney Harbour, on the coast of New South Wales. This rise in sea-level ultimately created the Australia we know today (Figure 1.4).

Australia has a distinctive coastal outline (Chapter 6). It has a convex-shaped western and eastern coast, a large bight in the south, and three northward-pointing promontories (Figure 1.4): the Kimberley (WA), Arnhem Land (NT) and Cape York Peninsula (Qld). The submerged extensions of the continent form a differently shaped Australia. Some of these submerged regions ( $<125 \mathrm{~m}$ below sea-level [bsl]) were land bridges and freshwater lakes during the last ice age (Figure 1.2). In total, the continental extensions of Australia are 1.8 times larger than the exposed landmass (Table 1.1).

Because of its geographical position in the Southern Hemisphere, distant from the European and North American powers, Australia has colloquially been known as the land down under. Many books and songs have used this term. Geoffrey Blainey wrote about the Tyranny of Distance, referring to Australia's geographical position being far from the major powers and economies. In the Oceania region, however, Australia now has a dominant influence; it is the largest and most populous country, and has the largest economy and the most powerful military in the region.

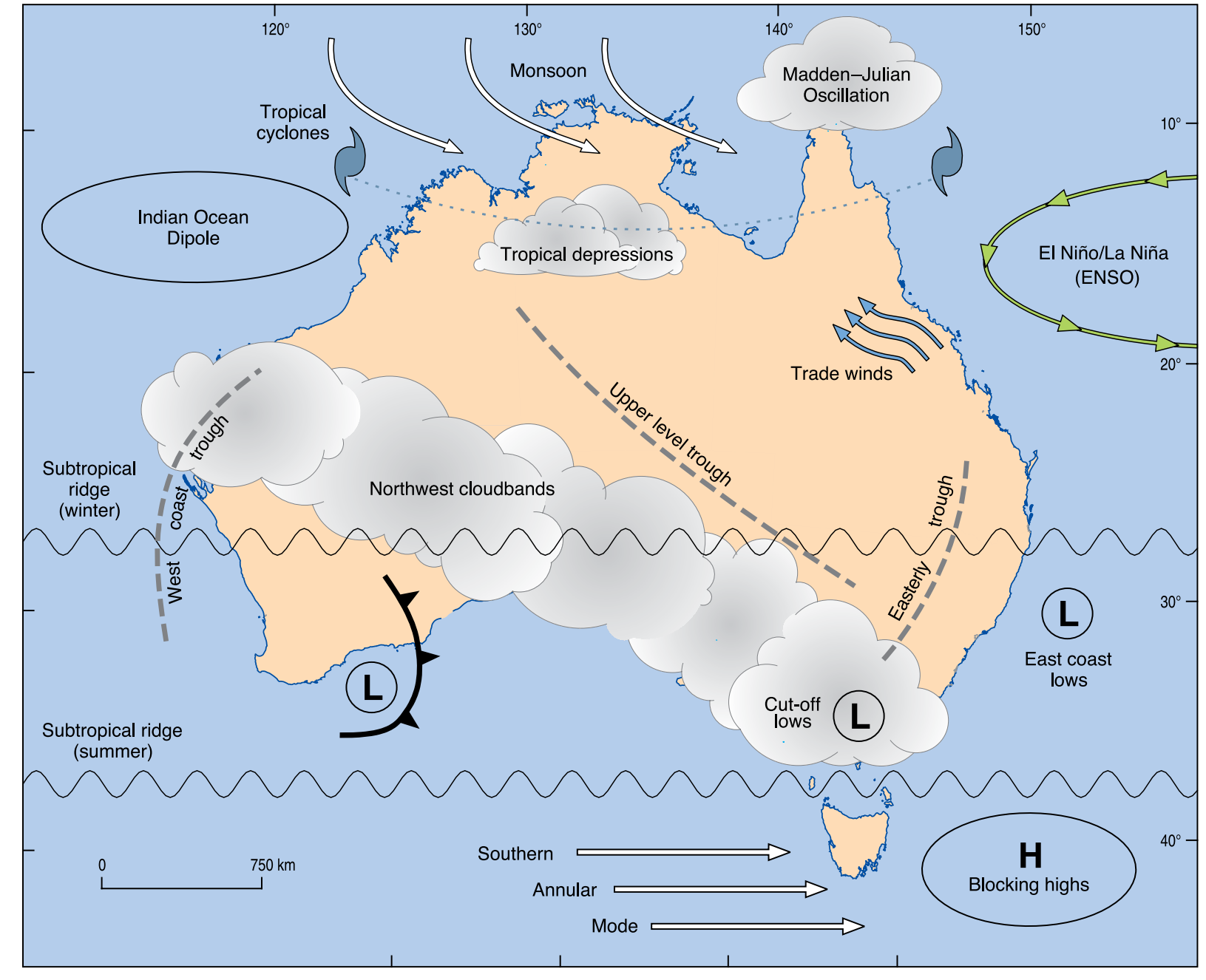

\section{Australian landscape: the flattest on Earth}

The topography of the continent of Australia is subdued. With an average elevation of only $325 \mathrm{~m}$, Australia is the lowest of all continents. Without major mountains, Australia's river systems have low and erratic flow rates compared with those on other continents (Chapters 5 and 7). Limited river systems have had a major influence on the availability of surface water, as well as navigable passageways into the continent.
Figure 1.6: Australia's climate can vary greatly from one year to the next. The map shows the present main influences on Australia's climate. These influences have varying levels of impact in different regions at different times of year. (Source: Bureau of Meteorology) 


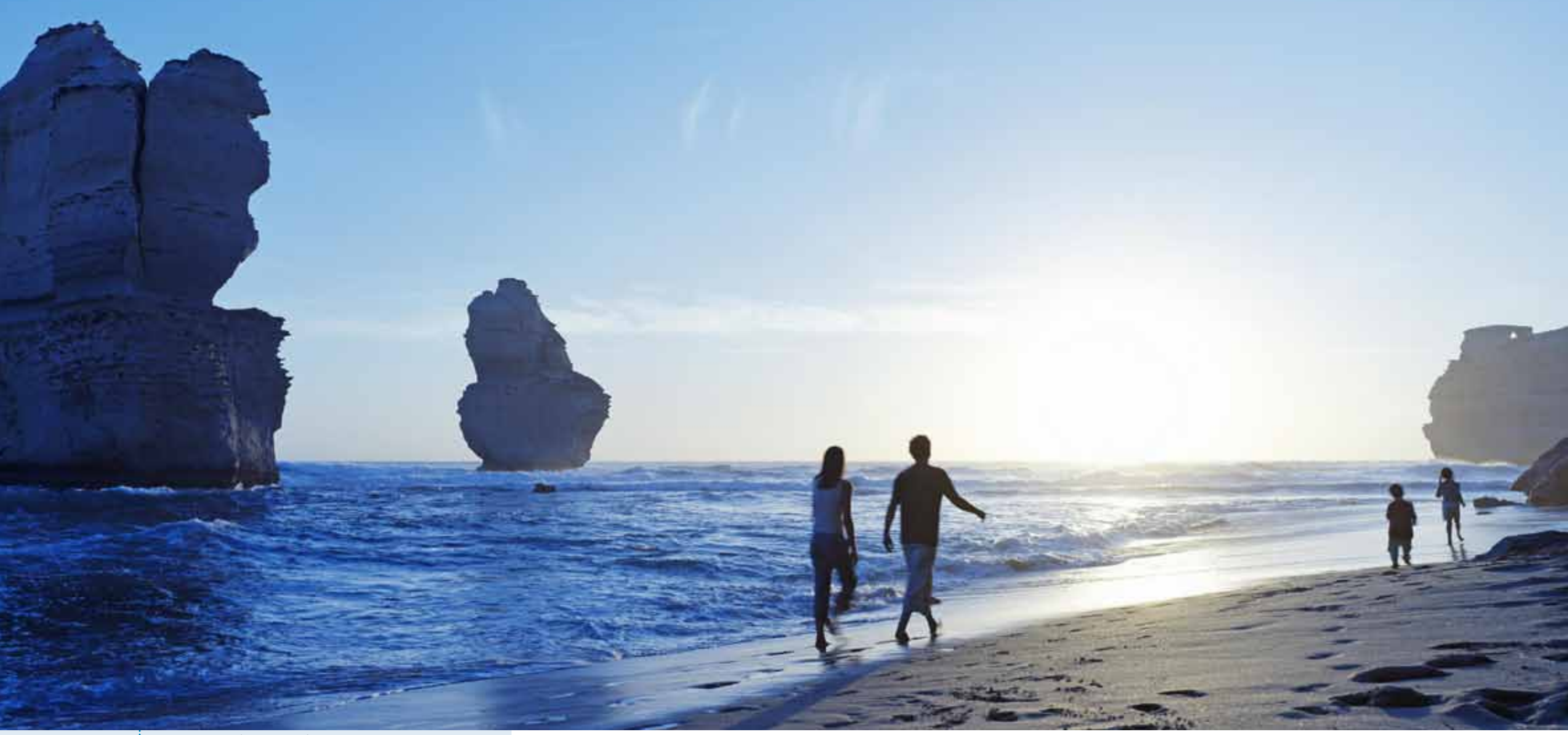

Image courtesy of Tourism Australia

- The Twelve Apostles sea stacks are a popular tourist destination along the Great Ocean Road, Victoria.
The major physiographic features of the Australian continent are a large Western Plateau with localised ranges; the Eastern Uplands, with the highest land concentrated along the Great Divide; and an intervening zone of Interior Lowlands (Figure 1.5). The highest point on the continent, Mt Kosciuszko, is only $2228 \mathrm{~m}$ asl, and the lowest point is Lake Eyre at around $15 \mathrm{~m}$ bsl (Box 1.5).

The lack of elevation across Australia is more than compensated for in landscape variety. In the centre and the west, there are vast stony and sandy deserts; in the east, sweeping plateaus and plains flank narrow coastal slopes. Australia's coastal features vary considerably, with broad, sandy beaches, lush vegetation, stark deserts, steep cliffs, swamps and mangroves, and extensive tidal flats (Chapter 6). These various coastal environments are backed by a great variety of landforms, ranging from the steep cliffs of the Blue Mountains west of Sydney, and the eroded volcanic edifices of the Glasshouse Mountains north of Brisbane, to the monotonous flatness of the Nullarbor Plain on the southern coast. The giant monolith Uluru in the Northern Territory (Box 1.1) and the striking beehive mountains of Purnululu (the Bungle Bungles) in Western Australia attract visitors from around the world, as do the country's beaches and rainforests. Many of these geological features are World Heritage listed. 


\section{Australian climate: beautiful one day_perfect the next}

Continental drift has positioned Australia in its current latitude, ensuring that it is mostly hot, dry and sunny (Figures 1.6 and 1.7). The Australian Energy Resource Assessment (AERA) estimates that around $58 \mathrm{M}$ petajoules $(\mathrm{PJ})$ of solar radiation fall on the land surface, which is 10000 times the current energy consumption. Australia has the highest solar radiation per square metre of any continent, and it is especially high in the northwest and centre of the country (Figure 10.1).

The abundant solar resource comes with a sting. The ultraviolet light levels are often extreme in Australia, especially between 10:00 am and 2:00 pm. For a predominantly fair-skinned population, this means that Australians have the highest skin cancer rates in the world. Various government programs have emphasised the slip (shirt)-slop (sunscreen)-slap (hat) strategy to encourage Australians to manage their risk. These programs have been extended to include seek (shade) and slide (sunglasses).

Heat accompanies such a sunny climate. Other than epidemics and war casualties, heatwaves, such as those during the summers of 1895-96 and 1938-39, have been responsible for more deaths (more than 400 each) than any other climate factor or disaster. As recently as February 2009, even with modern air-conditioning, some 374 people perished in the extreme heat. That heatwave was also one of the catalysts for the disastrous Black Saturday fires in Victoria, which killed 173 people and burnt $4500 \mathrm{~km}^{2}$ of country that had endured a decade of drought.
All regions in Australia enjoy warm summers and relatively mild winters (Figure 1.7); it rarely snows in most state capitals. The highest temperature ever recorded in Australia was $53^{\circ} \mathrm{C}$ in 1889 at Cloncurry, Queensland. The coldest temperature was $-23^{\circ} \mathrm{C}$, recorded in 1994 at Charlotte Pass in the Snowy Mountains, New South Wales. The Snowy Mountains are Australia's main winter sport playground, with skiing from June until October. Although Australia's snowfields are not world class in vertical drop or snow quality, they occupy an area of around $1200 \mathrm{~km}^{2}$ (for two months), which is similar to the area of permanent snow and ice in Switzerland.

As an island continent, Australia, more than any other continent, is subject to the influence of interseason climate variations, especially with respect to rainfall (Figure 1.8). These influences, illustrated in Figure 1.6, include the:

- El Niño/La Niña-Southern Oscillation (ENSO), which is a climate pattern across the tropical Pacific Ocean

- Indian Ocean Dipole (IOD), which is a measure of sea-surface temperatures between the western and eastern Indian Ocean

- Southern Annular Mode (SAM), also known as the Antarctic Oscillation (AAO)

- Madden-Julian Oscillation (MJO), which is a global-scale feature of the tropical atmosphere and influences the monsoon in northern Australia (Figure 1.6).

The ENSO index is calculated from monthly or seasonal fluctuations in the air-pressure difference between Tahiti and Darwin, which is a major

\section{Did know?}

\section{3: There are six 'seasons' in the Top End}

The traditional owners of the Northern Territory's Arnhem Land describe six distinct seasons. These different times guide the peoples' cultural and spiritual practices:

- Gudjewg, from December to March, can be described as the 'true' wet season.

- Banggerreng, in April, is the season of clear skies.

- Yegge, from May to mid-June, is relatively cool, but humidity remains.

- Wurrgeng, from mid-June to mid-August, is the 'cold weather time'; humidity is low.

- Gurrung, from mid-August to mid-October, is hot and dry.

- Gunumeleng, from mid-October to late December, varies from a few weeks to months, and is the pre-monsoon season of hot weather with progressively more and more humidity.

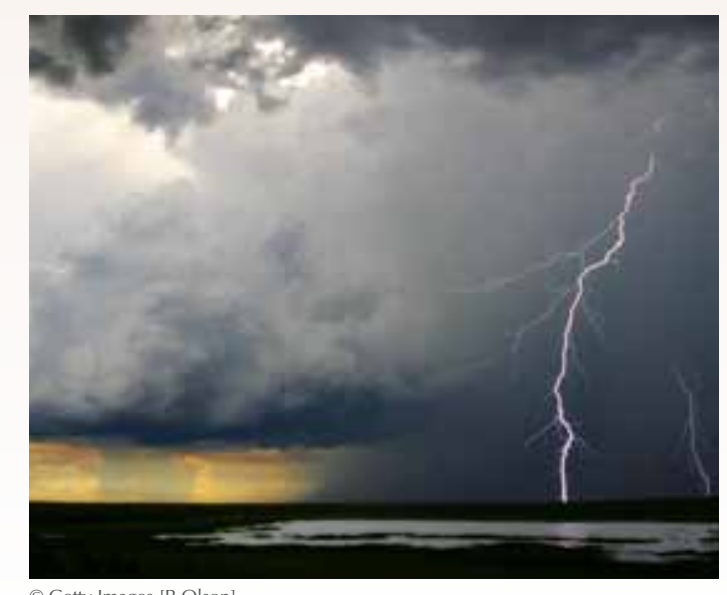



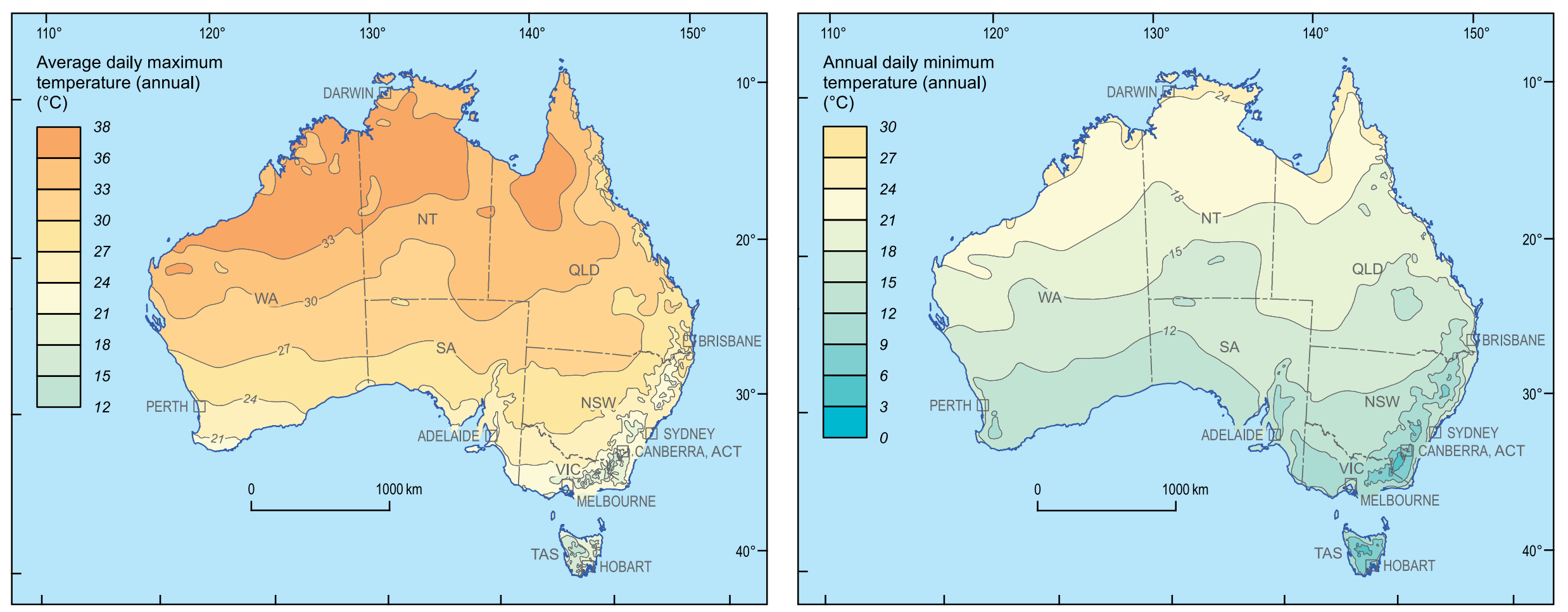

Figure 1.7: Average daily maximum and minimum temperatures. (Source: Bureau of Meteorology) factor in controlling Australia's rainfall. Sustained negative values indicate El Niño episodes, which are usually accompanied by sustained warming of the central and eastern tropical Pacific Ocean, a decrease in the strength of the Pacific trade winds, and a reduction in rainfall over eastern and northern Australia. Positive values are often associated with La Niña episodes, which lead to stronger Pacific trade winds and warmer sea temperatures to the north of Australia. Waters in the central and eastern tropical Pacific Ocean become cooler. Together, these factors increase the probability of rain in eastern and northern Australia.

The national average annual rainfall of $470 \mathrm{~mm}$ varies greatly each year and is distributed unevenly around the continent (Figure 1.8). In fact, the one thing that is predictable about Australia's rainfall is that it is unpredictable. In general, southern Australia has four seasons in terms of temperature, but not necessarily rain. The tropical north of the continent has two dominant seasons, with a relatively warm and dry winter, and a summer monsoon (December-March) known as the 'wet' season (see Did you know? 1.3).

The most arid area in Australia is the centre of the continent, particularly the Lake Eyre Basin, which averages less than $125 \mathrm{~mm}$ annually (Figure 1.8). Arid areas such as these have very considerable variability in rainfall, with several years' worth of rain falling from a single major weather system, such as in 2009-10. Birdsville in outback New South Wales has an annual average rainfall of $133 \mathrm{~mm}$. In 1917, some $659 \mathrm{~mm}$ of rain was recorded, while seven years later, in 1924, only $14 \mathrm{~mm}$ was recorded. 

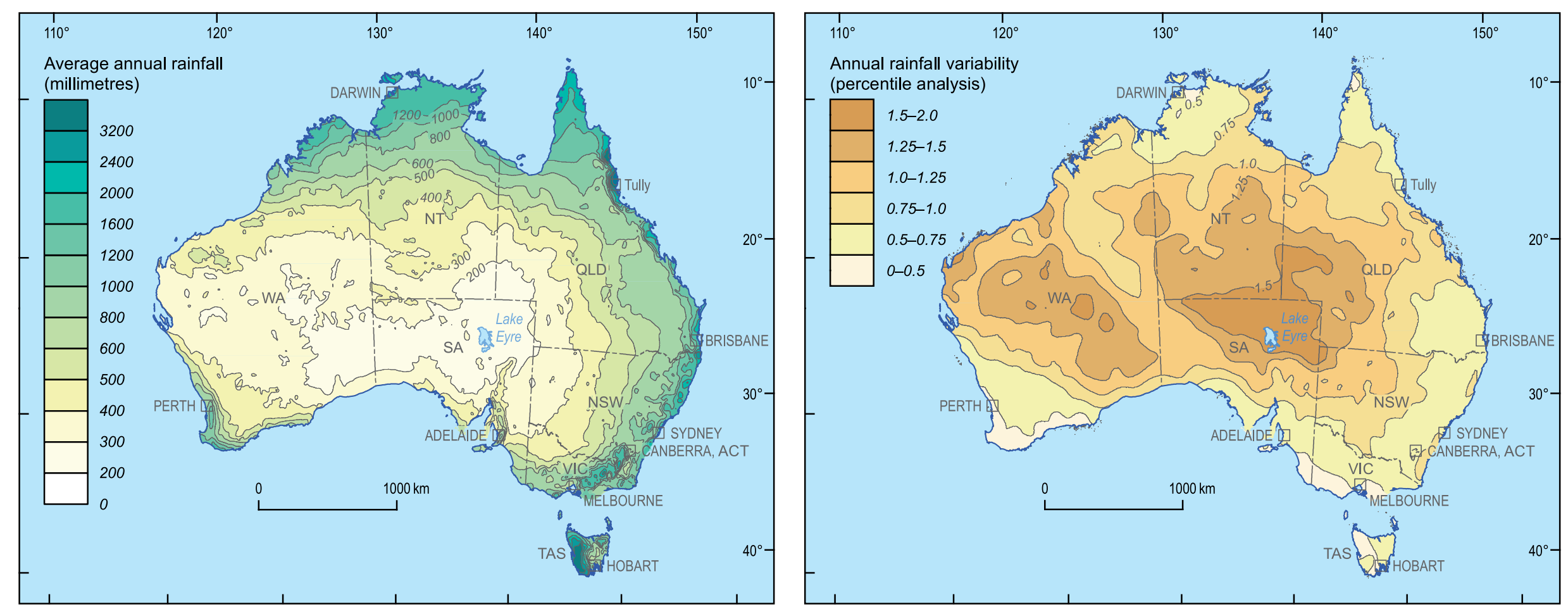

The desert areas of Australia are much wetter than deserts in Africa and South America, which average less than $50 \mathrm{~mm}$ per year. The relatively warm encircling oceans (Chapter 6) and the lack of blocking mountain ranges (Chapter 5) ensure that some precipitation usually falls on inland Australia. Both surface water and groundwater are scarce (Chapter 7). Water is therefore a point of dispute between those wanting to use it, such as for agriculture or mining, and those wanting to preserve it, for environmental flows.

The wettest regions of Australia are located in the tropical northeast and in the far southwest of Tasmania. The mountains in the hinterland of Tully in northeast Queensland have recorded (in 2000) more than $12 \mathrm{~m}$ in annual rainfall. The town is Australia's wettest, with average annual rainfall of more than $4 \mathrm{~m}$. Rain on the western and southern coasts of the mainland falls primarily in the winter, whereas the east coast receives rain in all seasons, with more during the summer. The summer of 2010-11 was particularly wet, with catastrophic flooding throughout Queensland and northeast New South Wales, resulting in many fatalities. The summer of 2011-12 repeated this pattern, thankfully without the fatalities. The driver of these events is thought to be a particularly strong La Niña event. These floods followed a decade of drought in eastern Australia. As captured by Mackellar in 1904-'of droughts and flooding rains - southern Western Australia remained very dry. There were persistent temperatures above $40^{\circ} \mathrm{C}$ in the summer of 2011 , which resulted in bushfires that burned houses in the suburbs around Perth.
Figure 1.8: Average annual rainfall (1961-90) and rainfall variability. (Source: Bureau of Meteorology) 


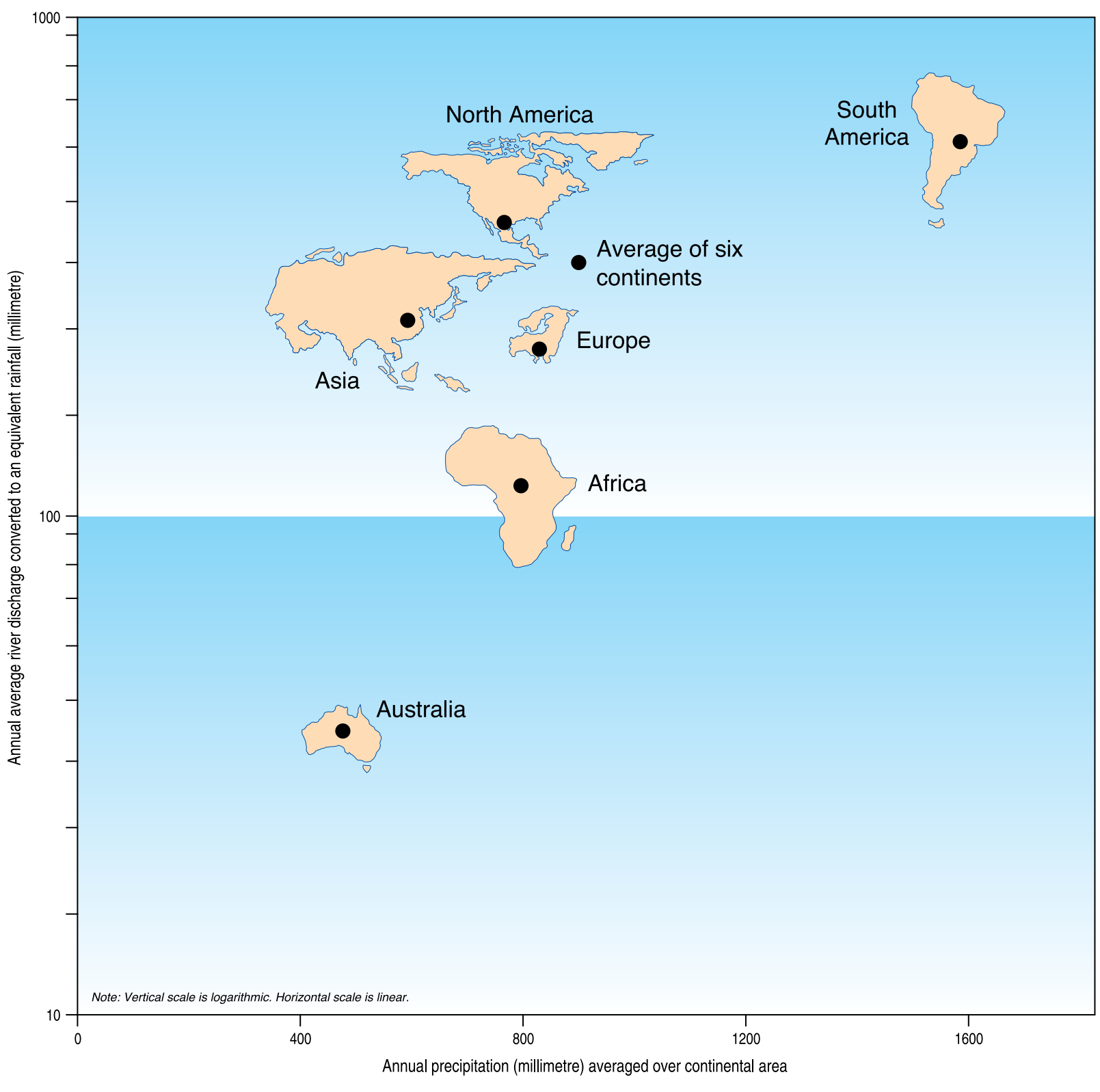

Figure 1.9: Australia's precipitation budget compared with the other inhabited continents. Australia is a standout, with low rainfall and low river discharge. (Sources: Lamont-Doherty Earth Observatory; Bureau of Meteorology, 2009)

\section{Australian water and soils: short but not sweet}

In the driest inhabited continent (Figure 1.9), Australia's environment and people face the persistent challenge of securing water. Even with the addition of water, Australia's soils are not very productive (Chapter 5). They are old and fragile and prone to damage and erosion, especially when subjected to European industrial-scale agricultural practices.

About one-third of the Australian mainland lies north of the Tropic of Capricorn, with the remainder stretching to latitude $39^{\circ} \mathrm{S}$ (Figure 1.4). About $70 \%$ of the country is arid or semi-arid, and a large part of the centre is unsuitable for large-scale settlement. More than one-third of the continent is classified as desert. There are 11 principal deserts, the largest of which is the Great Victoria Desert, spanning $348750 \mathrm{~km}^{2}$ (4.5\% of the continent) through Western Australia and South Australia (Figure 1.4). As a consequence, Australia's rivers have the world's lowest amount of discharge into the sea of any continent (Figure 1.9). This lack of discharge has had a major influence on the physical shaping of the coast's geomorphology, such as ports and harbours, or lack thereof (Chapter 6).

Australia's Murray and Darling rivers make up one of the great river systems of the world in terms of areal drainage. Together, their catchments form the $1 \mathrm{M}$ $\mathrm{km}^{2}$ Murray-Darling Basin, which covers around $14 \%$ of the mainland area. Throughout human history, rivers have provided geographical barriers, as well as corridors for exploration, settlement and development. However, the generally low flow 
Early explorers searched in vain for a vast 'inland sea'; the time was not right for them to see one of Australia's most fascinating places. Instead, they found mostly arid country with few people and signs of life. But there are 'inland seas' both past and present. Lake Eyre in South Australia is Australia's largest salt lake and is situated within a major internal river drainage system of the interior lowlands. It actually comprises two modern lakes, North Lake Eyre and South Lake Eyre, which are now connected by a narrow channel. Almost three-quarters of the runoff from Lake Eyre's $1.3 \mathrm{M} \mathrm{km}^{2}$ catchment finds its way via an intricate network of channels known as the Channel Country through the deserts to its north and east towards Lake Eyre.

Although most of the water is lost through evaporation or absorption, on the rare occasions when the lake fills, it temporarily becomes Australia's largest lake as it spreads out over a vast area and reaches almost $6 \mathrm{~m}$ at its deepest point. Then it becomes a wildlife haven and is renowned for the swift return of primitive fairy shrimps, fish, and vast numbers of breeding birds, including pelicans.

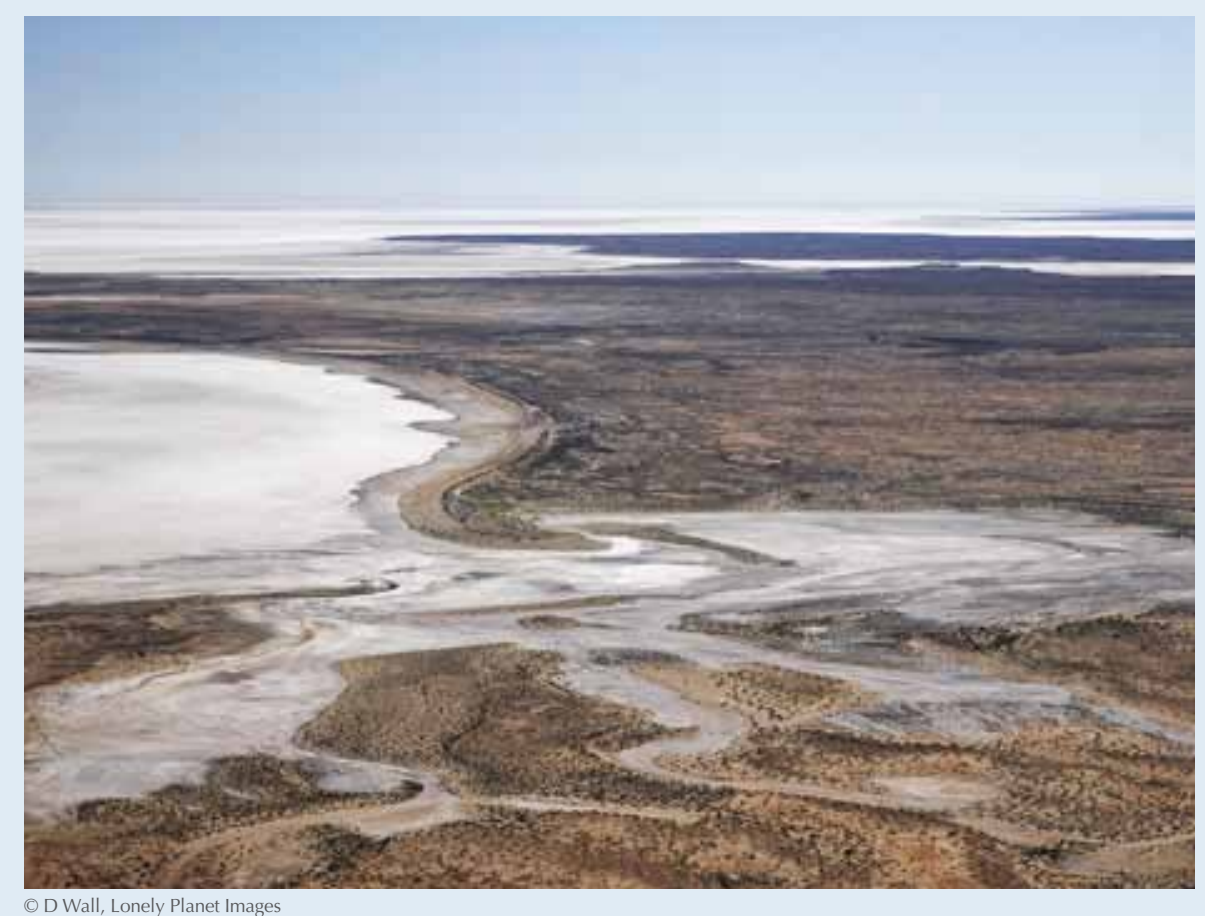

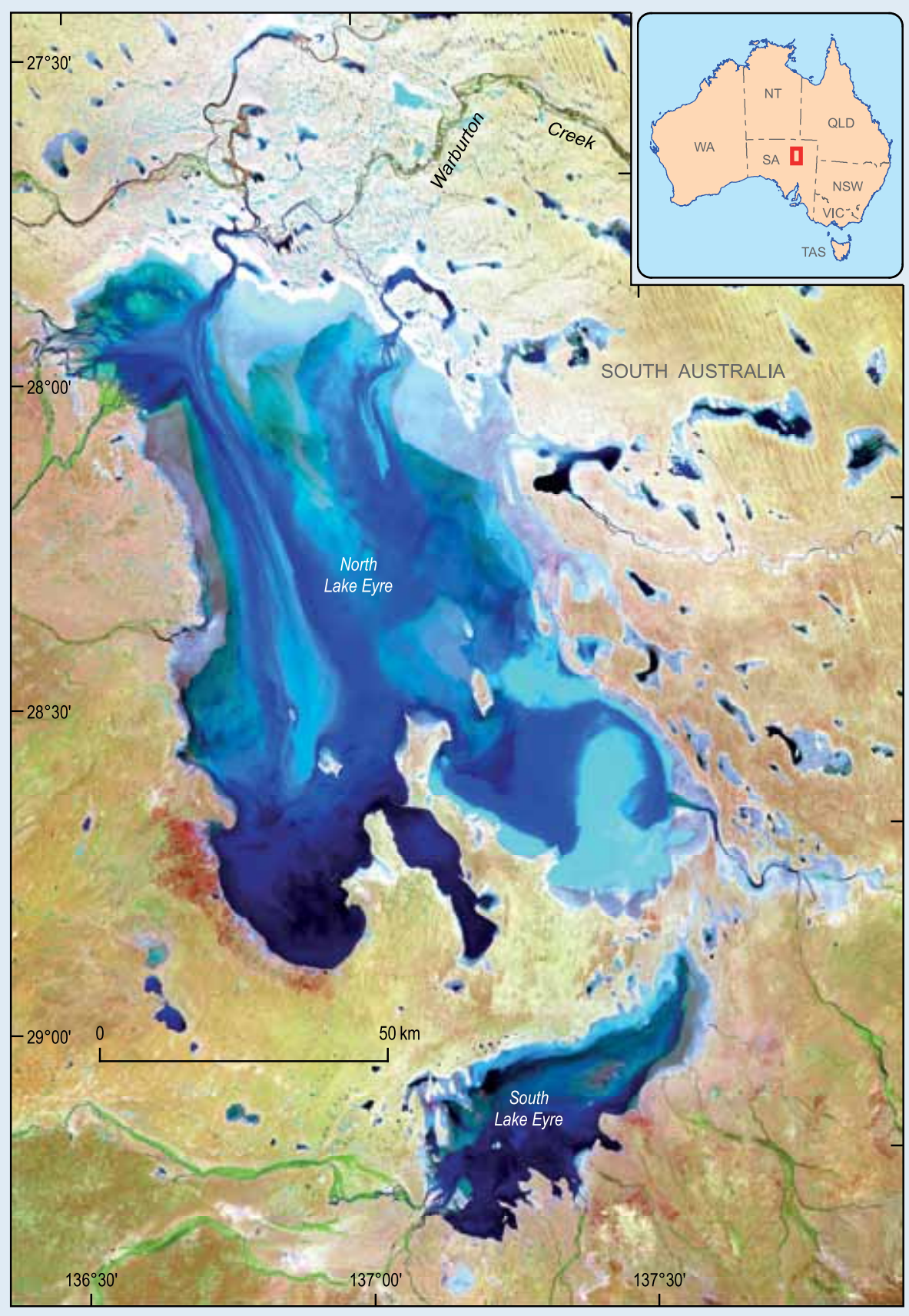



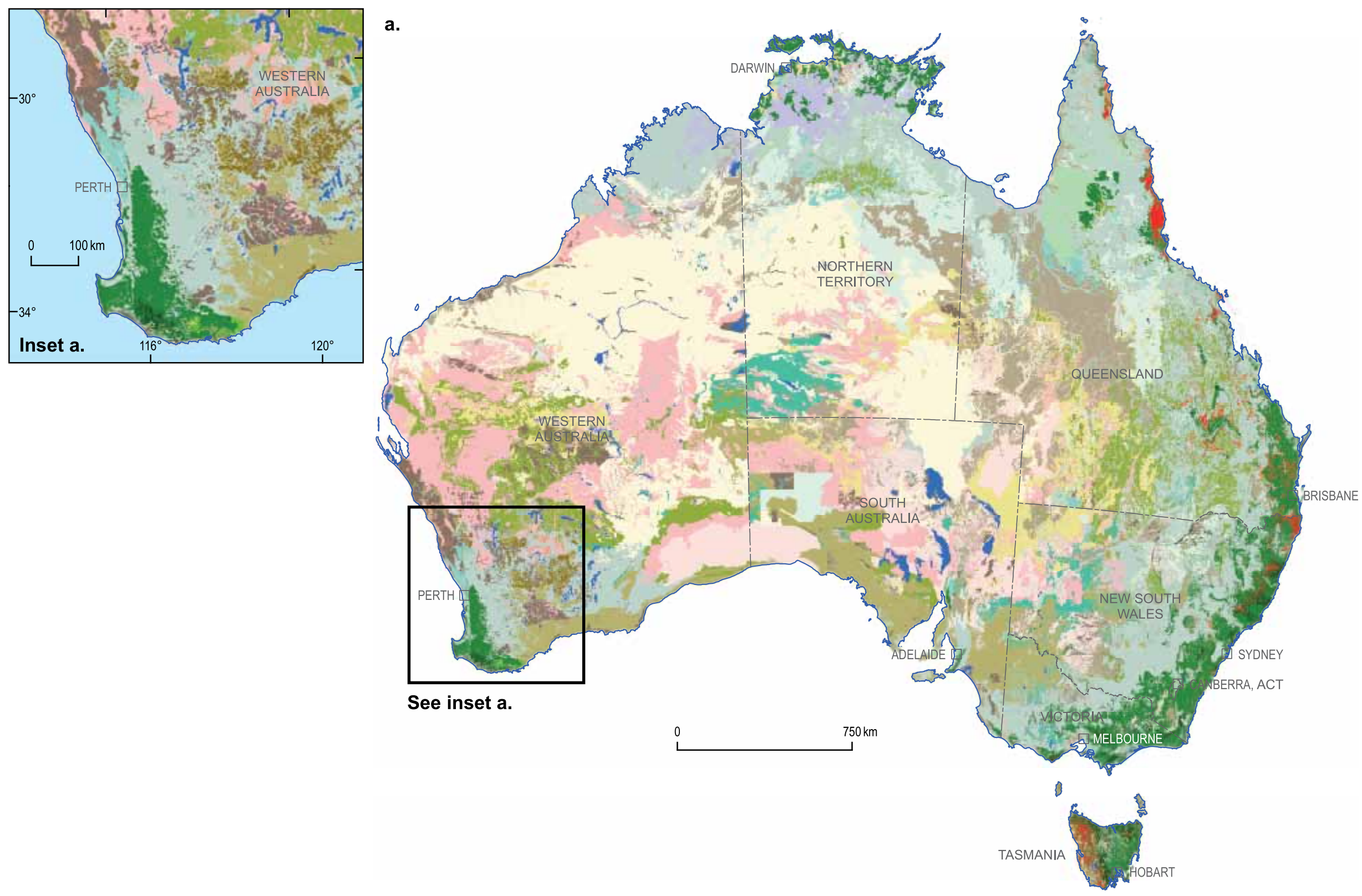

\begin{tabular}{|c|c|c|}
\hline Rainforest and vine thickets & Acacia forests and woodlands & Eucalyptus open woodlands \\
\hline Eucalyptus tall open forest & Callitris forests and woodlands & $\begin{array}{l}\text { Tropical eucalyptus } \\
\text { woodlands/grasslands }\end{array}$ \\
\hline Eucalyptus open forest & Casuarina forests and woodlands & Acacia open woodlands \\
\hline Eucalyptus low open forest & Melaleuca forests and woodlands & Mallee woodlands and shrublands \\
\hline Eucalyptus woodlands & Other forests and woodlands & $\begin{array}{l}\text { Low closed forest and tall closed } \\
\text { shrubland }\end{array}$ \\
\hline
\end{tabular}


b.

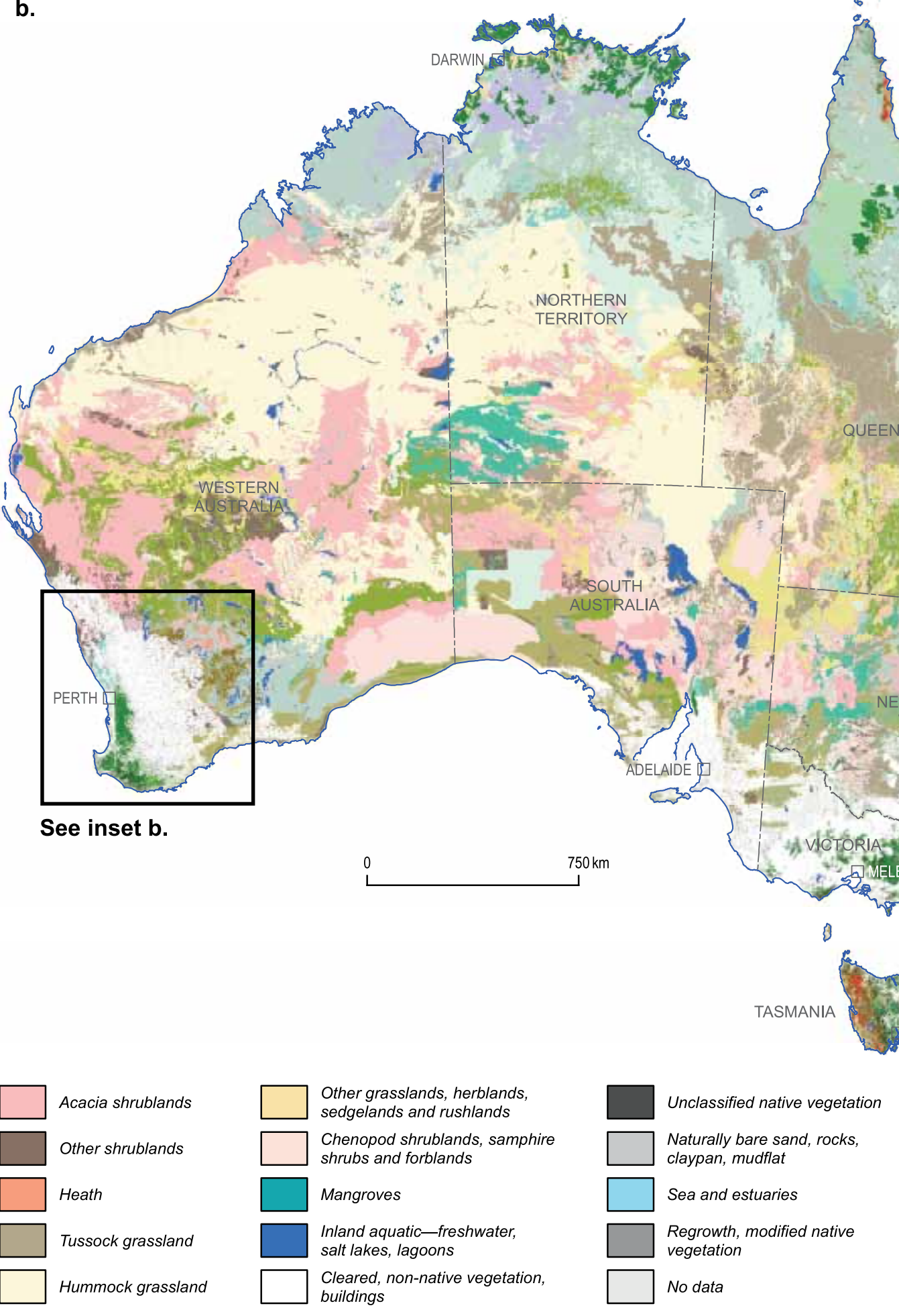

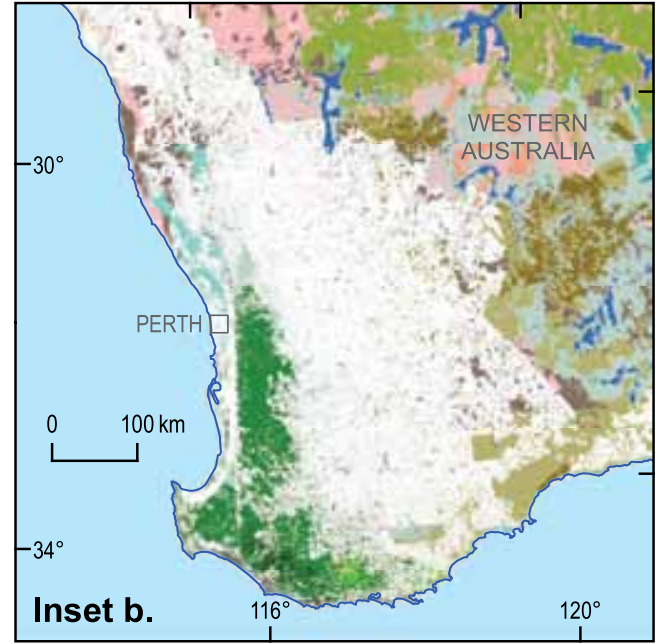

BRISBANE

Inset $b$.
Figure 1.10: Vegetation patterns (a) pre-1788 and (b) 2000 The impact of European settlement is most marked in the coastal zone, with substantial modification, especially the clearing of vegetation for agriculture (the white areas) and the fragmentation of the original vegetation. Compare the changes in the boxed area in the southwest of Western Australia. This region is identified as one of the world's biodiversity 'hotspots'. This unique environment is under pressure from agricultural expansion, excessive fertiliser use and invasive feral species (Chapter 3). 


\section{Did Yow?}

\section{4: Unique Australia}

- Australia has around $10 \%$ of the world's biodiversity.

- Southwest Australia, one of the world's five Mediterranean-type ecosystems, is listed as a unique biodiversity 'hotspot'.

- Of the estimated 20000 species of vascular plants found in Australia 16000 are found nowhere else in the world.

- Of the 378 species of mammals in Australia, more than $80 \%$ are endemic.

- Of the 869 Australian reptiles, 773 are found nowhere else.

- Around $80 \%$ of the marine biota of the Southern coast are endemic.

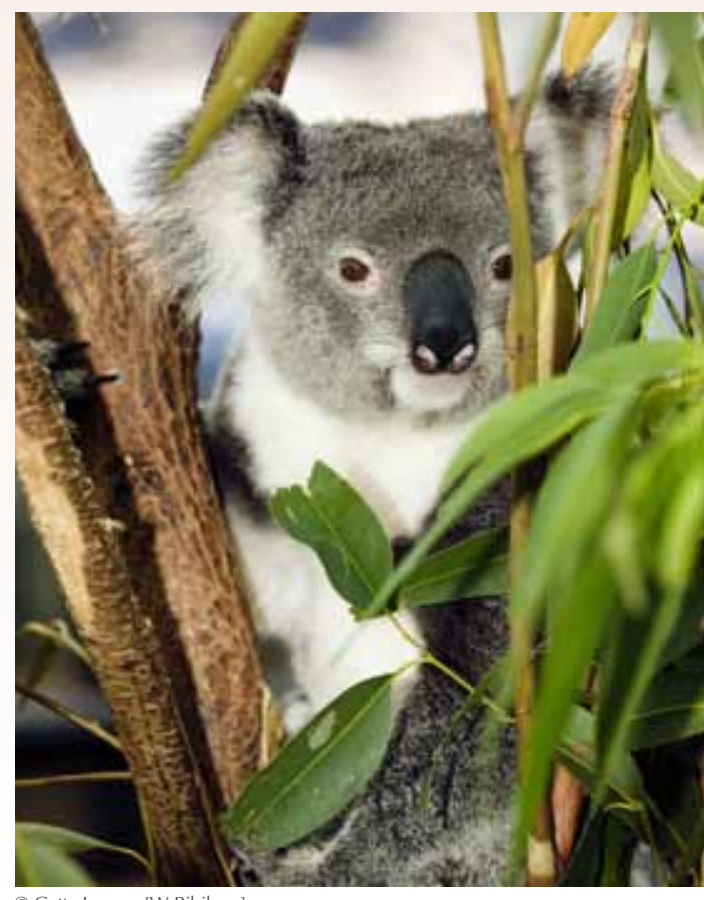

The capacity of a land's biota for domestication is a prerequisite for a reliable food supply, an essential input for the development of large human populations and complex societies. Contrast the food value of rice, wheat and corn, endemic to other continents, with Australia's spinifex and other native grass seeds. Contrast the utility of mammals such as horses, cattle, sheep and goats, endemic to most other continents, for food and work with Australia's marsupials_kangaroos, koalas and wombats.

Australia is a land like no other, with about a million different native species (Chapter 3), and yet only the macadamia nut tree has been successfully domesticated for human food supply on any large commercial scale. Aboriginal and Torres Strait Islander people occupied a land that not only became increasingly dry, but also had little in the way of natural resources amenable to domestication. Australia's large agricultural industry has been built on imported species of flora and fauna, which have led to many environmental problems.

The partial isolation of the Australian continent has also meant that more than $80 \%$ of the continent's flowering plants, mammals, reptiles and frogs are unique to Australia, along with most of its freshwater and even marine fishes and almost half of its birds (Chapter 3). Australia's marine environment is home to 4000 fish, 1700 coral, 50 marine mammal and 110 seabird species, about $75 \%$ being endemic. About $80 \%$ of marine species found in southern Australian waters occur nowhere else in the world, while only $10 \%$ of the known marine species in northern Australia are endemic.
Australia has more than 140 extant species of marsupials, including koalas, wombats and the Tasmanian devil (now found only in Tasmania). Australia (with New Guinea) hosts another unique animal group, the monotremes-egg-laying mammals, often referred to as 'living fossils'. The most distinctive is the platypus, a river-dwelling animal with a duck-like bill, a fur-covered body and webbed feet. This diversity has its drawbacks. Australia is infamous for its highly venomous and human-eating species, including spiders, snakes, sharks, crocodiles, jellyfish and stinging bushes, let alone biting flies and mosquitoes (Chapter 3) many of which curtail people's leisure pursuits, especially in the northern coastal areas.

The vegetation patterns in Australia today are strongly linked to the prevailing rainfall (Figures 1.8 and 1.10). Australian vegetation has evolved and adapted over time to the arid conditions, and so by global standards Australia's deserts are relatively densely vegetated. In the north, the extensive tropical forests grade south into more open scrub, and then into savannah zones where rainfall is less reliable (Figure 1.10). Vegetation patterns have changed during the last million years along with changing climate cycles (Chapters 3 and 5). The use of fire by Aboriginal people to promote open woodland and grasslands is also thought to have contributed to these changes (Chapter 3).

The development of extensive European-style agriculture based on imported species had a substantial impact on the pre-1788 vegetation patterns (Figure 1.10), with wholesale modification of habitats and fragmentation of vulnerable plant communities such as the tropical and temperate rainforests. Although the inland appears to have 
felt less impact, much is used for raising cattle. Even though cattle densities may sometimes be measured in square kilometres per animal, when the rains fail these hard-hoofed animals, unlike the native species, exact a high toll on fragile soils.

Australia has the world's third largest exclusive fishing zone, covering $11 \mathrm{M} \mathrm{km}^{2}$ and extending up to 200 nautical miles out to sea (Appendix 1.2.4). The east and west coasts of Australia have intermittent south-flowing warm currents, so the waters are less productive than for other continents, such as the west coasts of southern Africa and South America. Australia therefore only ranks $52 \mathrm{nd}$ in world volume of fish landed, with nearly $70 \%$ of the catch being exported (Chapter 6).

A relatively small number of Australian farmers feed, clothe and house many millions of people around the world. For example, Australia in 2009-10 produced around $22 \mathrm{Bt}$ of wheat, exporting more than half, with Indonesia, Malaysia and Japan being the largest importers. Other major agricultural exports include cotton, rice, timber products, beef, sheep, wool and fish. These energy-and water-intensive industries partly account for Australia's high per-capita generation of greenhouse gases (Chapter 10). Australia indirectly exports its scarce water through its resources. For example, about $960 \mathrm{~L}$ of water are used to make one litre of wine.

\section{Australian mineral and energy resources: wealth and choice}

Geology has ensured that Australia is an energy- and mineral-rich country by creating an abundance of coal, iron $(\mathrm{Fe})$, aluminium ( $\mathrm{Al})$, lead-zinc $(\mathrm{Pb}-\mathrm{Zn})$, gold $(\mathrm{Au})$, copper $(\mathrm{Cu})$, gas, rare earth elements and uranium $(\mathrm{U})$, to list a few (Appendix 8.1.1). There is a positive correlation between the size of a country, the age range of its rocks, and its mineral and energy wealth. This comes about partly because of the greater probability to form and then preserve a resource in a large area and the long period of geological time in which to do this. Australia wins on both counts (Boxes 1.3 and 1.4).

Aboriginal people have mined and traded in ochre and stone tools for millennia. The discovery of Australia's metalliferous mineral resources by new immigrants, however, is what helped to save the early colonies from economic ruin in the 1850s-first with $\mathrm{Cu}$ and later $\mathrm{Au}$. The allure of gold especially brought migrants from around the world and changed the social fabric of Australia forever (Box 1.2; Chapter 8).

Today, growth in Australia's economy is one of the highest in the Organisation for Economic Cooperation and Development (OECD), largely because of these mineral and energy resources. Australia's balance of trade is at a 146-year high, with much of this fortune driven by strong demand from the rapidly industrialising Asian economies (Chapter 9). Economic growth and energy use are strongly correlated, and Australians are lucky in having an assortment of energy choices. Coal is readily available and is the primary energy source; its use in electricity generation is one of the major reasons for Australia's high per-capita $\mathrm{CO}_{2}$ emissions. Uranium, gas in its various forms, and renewable energy, such as geothermal and solar power, provide alternatives (Chapter 10).

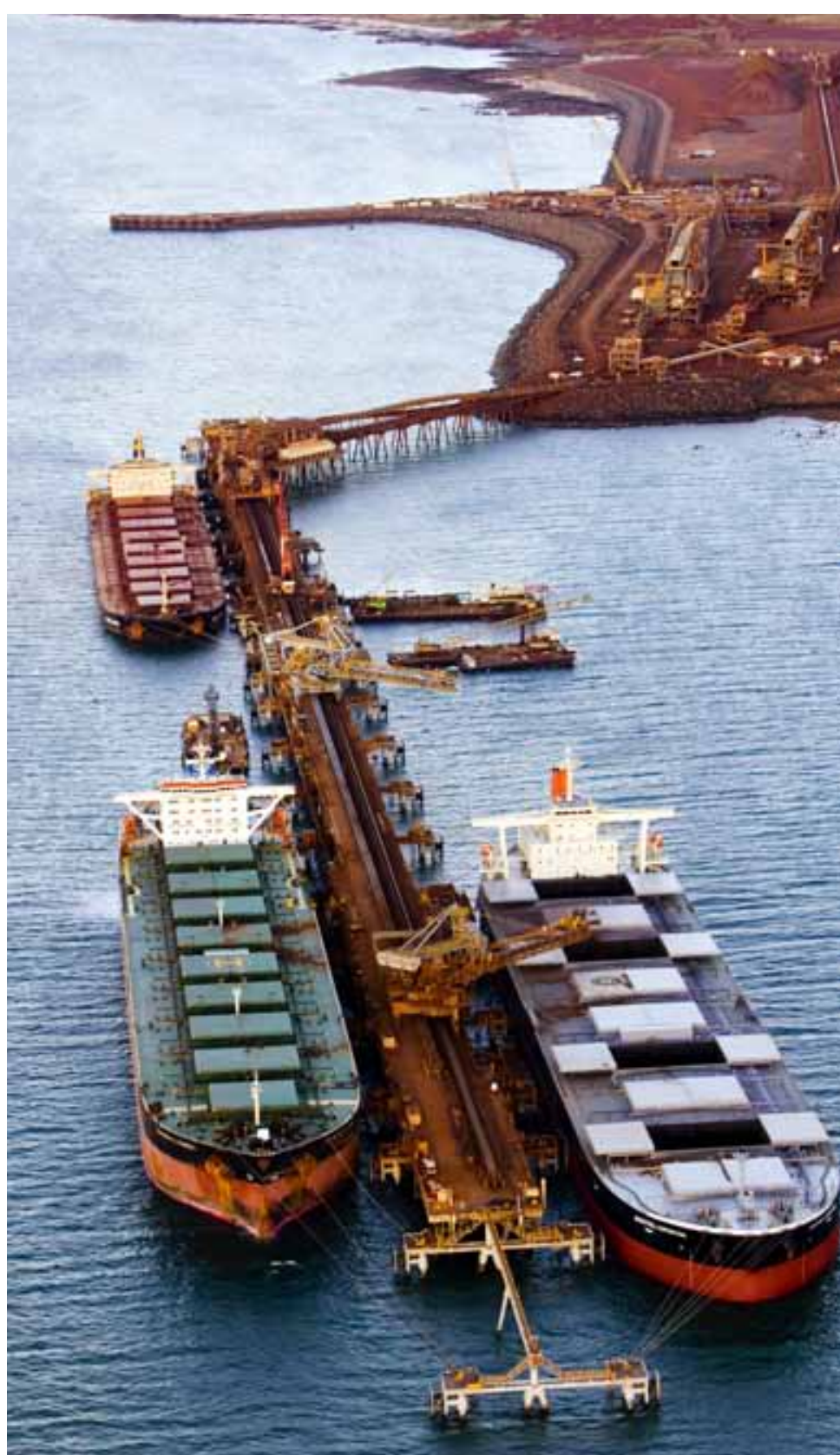

Image courtesy of Rio Tinto

Loading iron ore at Parker Point, Dampier Western Australia.

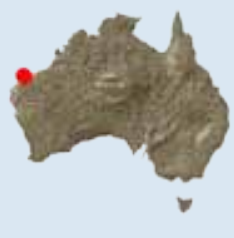


The favourable location of abundant high-quality coal in particular is a clear example of how geology has provided choices that have shaped the Australian people.

\section{Australian geohazards: living on the edge}

Australian people live distant from the active boundaries of the Australian Plate and the geohazards associated with large earthquakes and volcanoes. Australia, of course, is not immune to the destructive power of earthquakes-the fatal event in Newcastle in 1989 being the most significant example (Chapters 2 and 11). Most Australians, and much of Australia's economic infrastructure, is located close to the sea, making

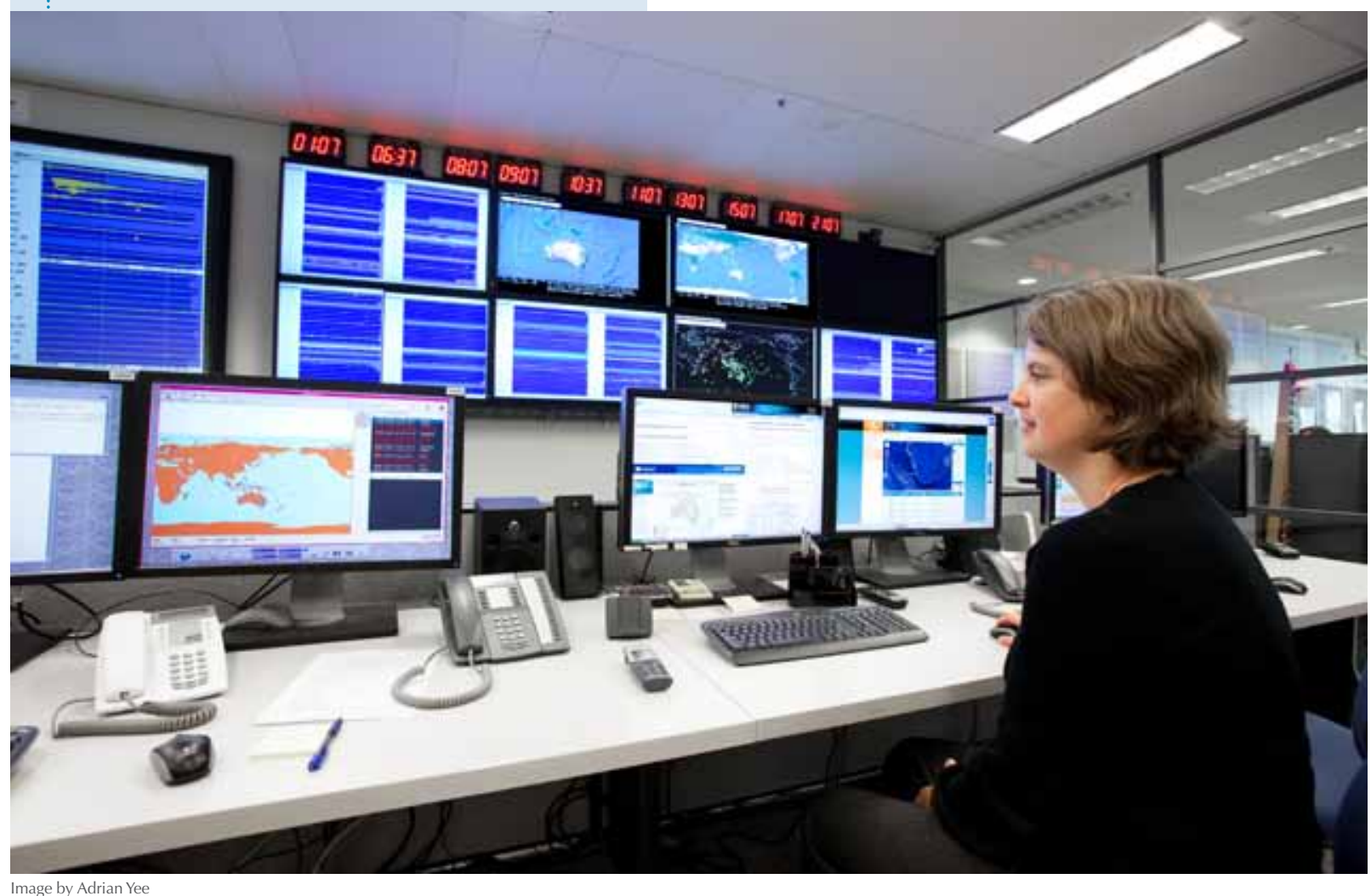

distantly generated tsunamis a potential major geohazard (Chapter 6). We do all live in one earth system, and the Chilean volcanic eruptions in mid-2011 grounded airlines in southern Australia, with the ash cloud circumnavigating the globe several times.

The geographical position and tectonic setting of the continent mean that cyclones, floods, droughts, bushfires and heatwaves are the primary geohazards for the Australian people. Climate change modelling indicates that such hazard impacts are likely to be greater in the future, with rising sea-levels also of great concern. As we improve understanding of how our plate responds to stress and unravel the changes in climate from a geological perspective, the Australian people will be better placed to make informed choices regarding their future protection from these geohazards. Of course, this can only happen with the 'consent of geology' (Figure 1.1).

\section{Knowing Australia's limits}

Here we think it is worth making a digression to understand Australia in terms of a legal definition. Most Australians live on mainland Australia or in Tasmania, only small populations live on the many smaller islands scattered about the nation's wider territory (Figure 1.3). Most people think of Australia as a large landmass of deserts and sweeping plains. Australia, however, is really a maritime nation with a confirmed marine jurisdiction of more than $14 \mathrm{M} \mathrm{km}^{2}$ (Frontispiece), which is almost twice the area of Australia's landmass (Table 1.1 and Appendix 1.2.4). 
Today, the country or sovereign nation of Australia consists of:

- mainland Australia and Tasmania, as well as many thousands of small fringing islands and numerous larger ones that rise from the shelf

- a number of remote mid-ocean islands that form parts of Australian states or Australia's external territories (Box 1.6).

Australia also claims the Australian Antarctic Territory, which is an area of nearly $6 \mathrm{M} \mathrm{km}^{2}$, or $42 \%$ of the total landmass of Antarctica (Table 1.1). The Australian Antarctic Territory has a combined coastline length of about $5500 \mathrm{~km}$. The highest point on the icecap occurs at $4100 \mathrm{~m}$, with the highest recognised mountains being Mt McClintock in the eastern sector at $3490 \mathrm{~m}$ and Mt Menzies in the western sector at $3355 \mathrm{~m}$. If the Antarctic Territory is included, Australia is the second largest country in the world.

\section{Australia's seas}

The basis for the granting of Australia's confirmed marine jurisdiction is lodged very much in geology (Frontispiece; Figure 1.11; Table 1.1). The geomorphological limits of Australia are defined by the foot of the continental slope or, where present, the continental rise. The continental slope covers around $6.8 \mathrm{M} \mathrm{km}^{2}$ (Table 1.1) and contains the continent's greatest variety of geomorphological features, the largest of which are related to rifting on all but the northern margin (Chapter 4). The slope around Australia contains an unusual number of large terraces and trough-bounded marginal plateaus. The geological limit of the continent

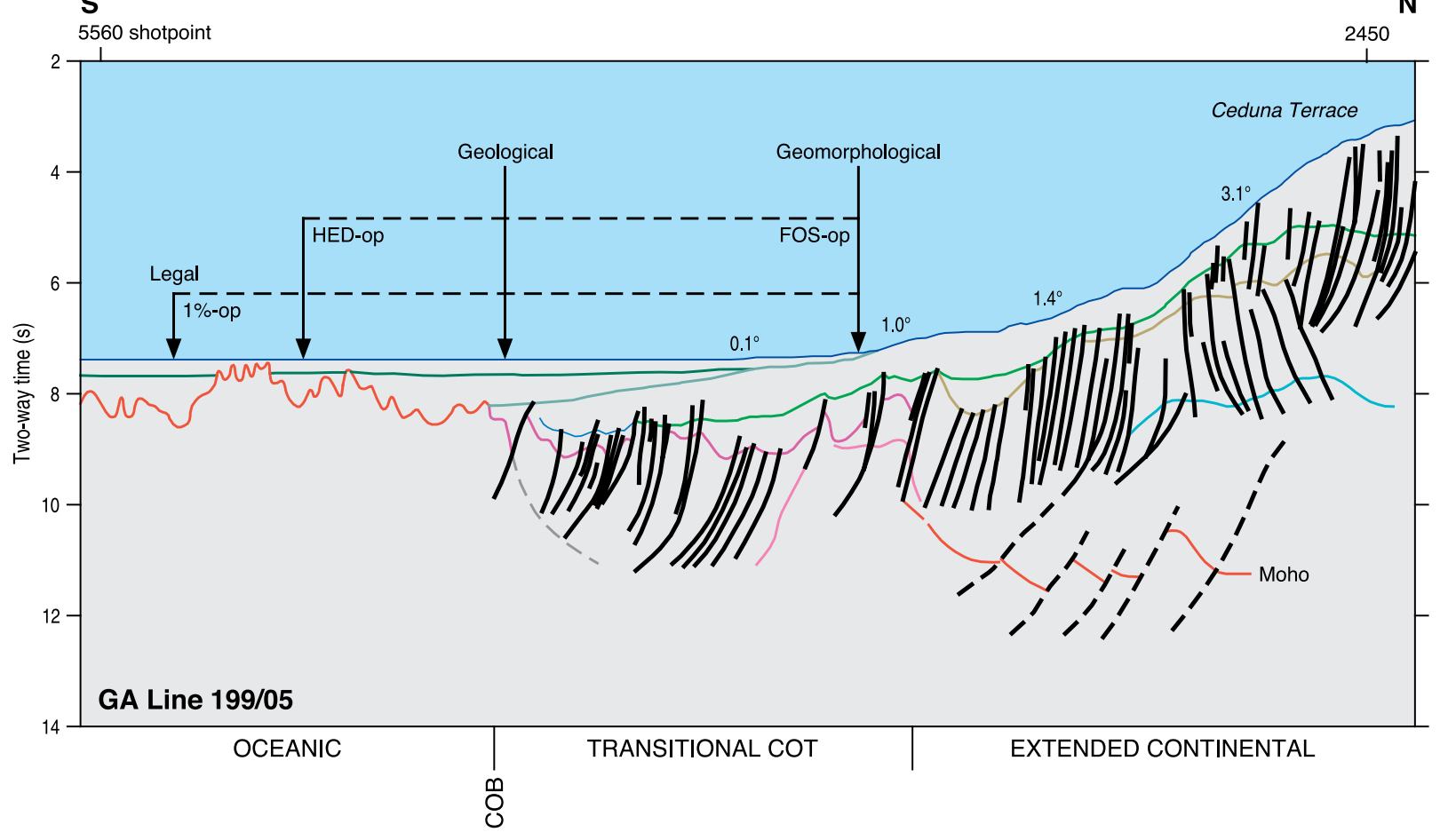

is defined by the continent-ocean boundary, which marks the change from extended, thinned and modified continental crust to unequivocal oceanic crust.

The margin adjacent to mainland Australia and Tasmania has a shelf of variable width (Frontispiece). In the east, the shelf break often lies within $15 \mathrm{~km}$ of the coast, and much of the margin comprises continental slope. The continental shelf is somewhat wider in the Great Australian Bight and in Queensland, where it acts as the base for the Great Barrier Reef. The extensive area of shelf to the north of Australia represents the extension of the Australian continent to the Java Trench and eastwards into Papua New Guinea, parts of the former Sahul landmass.
Figure 1.11: Continental margins and their geomorphological, geological and legal limits, explained by this interpreted seismic line across the Great Australian Bight margin of southern underlying Ceduna Sub-basin (Chapter 4), across the continentocean transition (COT) zone, continent-ocean boundary (COB) and onto the slow-spreading oceanic crust of the Southern Ocean. The location of the geomorphological, geological and legal limits to the continental margin is illustrated. Australia. The section is from the outer Ceduna Terrace and 
Table 1.1: Areas of Australia's land and maritime jurisdiction (see Frontispiece)

\begin{tabular}{|c|c|c|c|}
\hline Land & \multicolumn{2}{|c|}{ Area (million km²) } & \multirow{2}{*}{$\begin{array}{c}\text { \% surface area of Earth } \\
1.51\end{array}$} \\
\hline Australia and island external territories & & 7.69 & \\
\hline Australian Antarctic Territory & & 5.90 & 1.16 \\
\hline Total Australia/island territory/Australian Antarctic Territory land area & & 13.59 & 2.66 \\
\hline \multicolumn{4}{|l|}{ Internal waters } \\
\hline Approximate total marine area landward of territorial sea baseline (TSB) & & 0.26 & 0.05 \\
\hline \multicolumn{4}{|l|}{ Coastal waters (CW) } \\
\hline Internal waters & 0.24 & & \\
\hline Area 3 nautical miles seaward of TSB & 0.15 & & \\
\hline Total area of CW & & 0.39 & 0.08 \\
\hline \multicolumn{4}{|l|}{ Territorial sea (TS) } \\
\hline Australia and island external territories & & 0.68 & 0.13 \\
\hline Australian Antarctic Territory & & 0.17 & 0.03 \\
\hline State (coastal waters) 3 nautical mile portion of TS & 0.15 & & \\
\hline Commonwealth portion of TS & 0.70 & & \\
\hline Total area of TS (full 12 nautical mile zone) & & 0.85 & 0.17 \\
\hline \multicolumn{4}{|l|}{ Exclusive economic zone (EEZ) } \\
\hline Australia and island external territories & & 8.15 & 1.60 \\
\hline Australian Antarctic Territory & & 2.04 & 0.40 \\
\hline Total area of EEZ & & 10.19 & 2.00 \\
\hline \multicolumn{4}{|l|}{ Continental shelf a acommission on the Limits of the Continental Shelf } \\
\hline Continental shelf to 200 nautical miles (200CS) & & 10.19 & 2.00 \\
\hline Extended continental shelf (ECS) & Submitted & Confirmed & \\
\hline Australia and island external territories (see Frontispiece for locations) & 2.69 & 2.56 & 0.50 \\
\hline Australian Antarctic Territory—Australia requested the Commission ${ }^{a}$ not consider this region for the time being & 0.68 & & \\
\hline Total area of submitted ECS & 3.37 & & \\
\hline Total area considered by the Commission and yet to be resolved & 0.08 & & \\
\hline Total area of confirmed continental shelf $(200 \mathrm{CS}+\mathrm{ECS})$ & & 12.75 & 2.50 \\
\hline \multicolumn{4}{|l|}{ Australia's confirmed marine jurisdiction (TS+EEZ+ECS) } \\
\hline Australia and island external territories & & 11.39 & 2.23 \\
\hline Australian Antarctic Territory & & 2.21 & 0.43 \\
\hline Total area of Australia's confirmed marine jurisdiction & & 13.60 & 2.67 \\
\hline Australia's full confirmed marine jurisdiction (including marine areas landward of TSB to coast ca $0.26 \mathrm{M} \mathrm{km}^{2}$ ) & & 13.86 & 2.72 \\
\hline Australia's maximum possible marine jurisdiction & & 14.62 & 2.87 \\
\hline \multicolumn{4}{|l|}{ Australia's complete jurisdiction (land + full confirmed marine) } \\
\hline Australia and island external territories & & 19.34 & 3.79 \\
\hline Australian Antarctic Territory & & 8.11 & 1.59 \\
\hline Total area of Australia's complete, confirmed jurisdiction & & 27.45 & 5.38 \\
\hline
\end{tabular}


Australia's islands on the Kerguelen PlateauHeard Island and the McDonald Islands-are located $4100 \mathrm{~km}$ southwest of Perth (WA) and about $1500 \mathrm{~km}$ north of Antarctica. Heard Island was discovered by Captain Heard while sailing a great circle route from Boston to Melbourne in 1853. The McDonald Islands were discovered in 1854 by Captain McDonald.

The Kerguelen Plateau, which formed 118-110 Ma, is one of the largest volcanic plateaus in the world and is the largest in the Southern Ocean. It extends for more than $2200 \mathrm{~km}$ mostly in water depths of $1000 \mathrm{~m}$ to $4000 \mathrm{~m}$, but was emergent or under shallow water for up to $40 \mathrm{Ma}$, as indicated by wood fragments and coal found in Late Cretaceous sediments.

Heard Island and the McDonald Islands are home to Australia's only active volcanoes, with the most recent episodes of volcanic activity occurring on Heard Island since the mid-1980s, and on the McDonald Islands during the 1990s. The activity on the McDonald Islands group resulted in the island doubling in size and increasing in elevation by about $100 \mathrm{~m}$.

Heard Island has a land area of $368 \mathrm{~km}^{2}$ and is $43 \mathrm{~km}$ long. The island is dominated by the active volcano Big Ben, whose summit, Mawson's Peak, named for Australian geologist and Antarctic explorer Sir Douglas Mawson (Box 2.2), rises to $2745 \mathrm{~m}$ asl and is the highest Australian mountain outside of the Australian Antarctic Territory. Heard Island and the McDonald Islands were designated as World Heritage in 1997 because of their pristine sub-Antarctic ecosystems and geological activity.

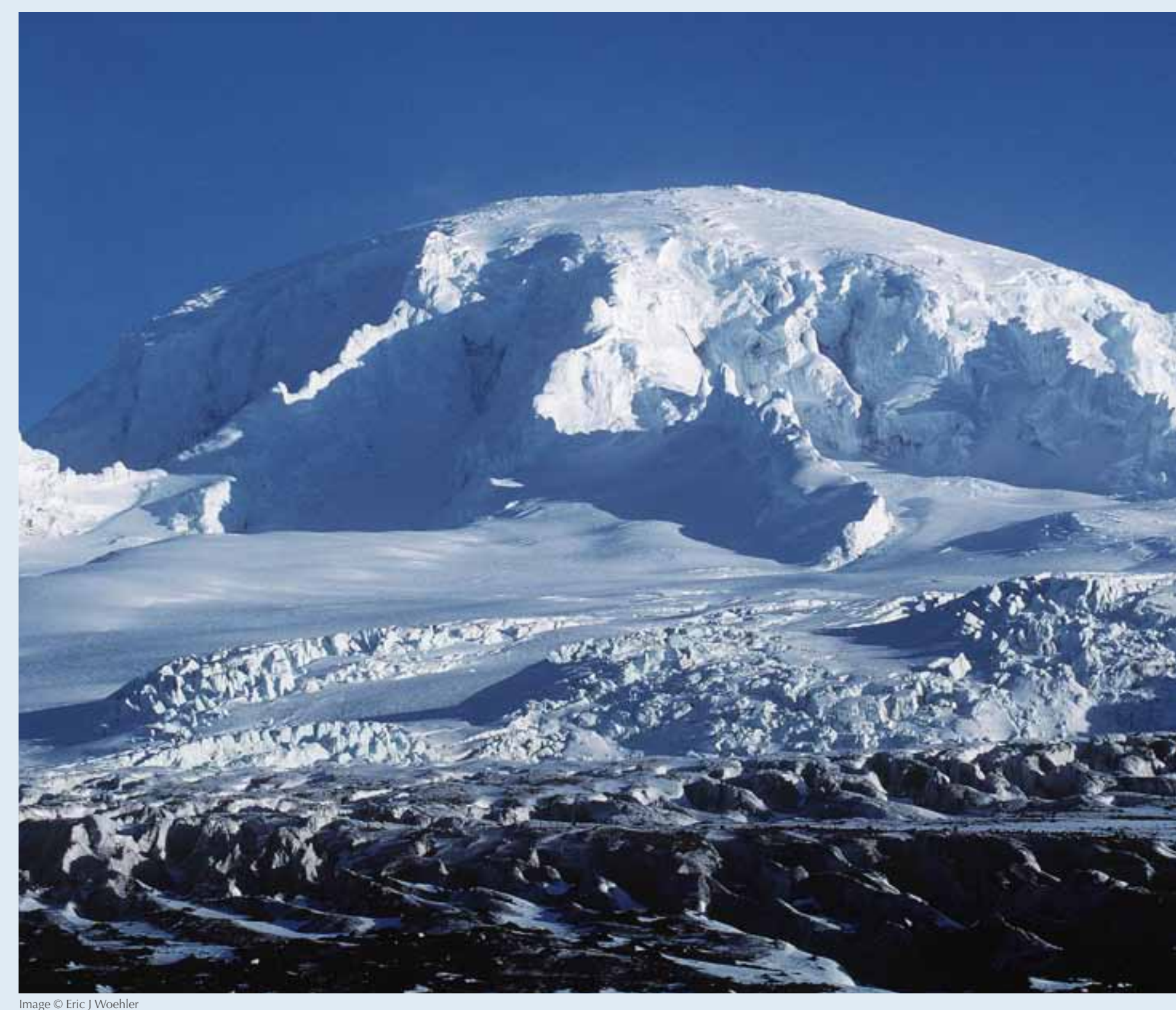

Figure B1.6: The modern-day Heard Island is dominated by Big Ben, a roughly circular active volcanic cone that rises $2745 \mathrm{~m}$ above sea-level. A number of glaciers descend the slopes of the mountain, including the Gotley and Lied glaciers, which are studied for their sensitivity to climate change. 

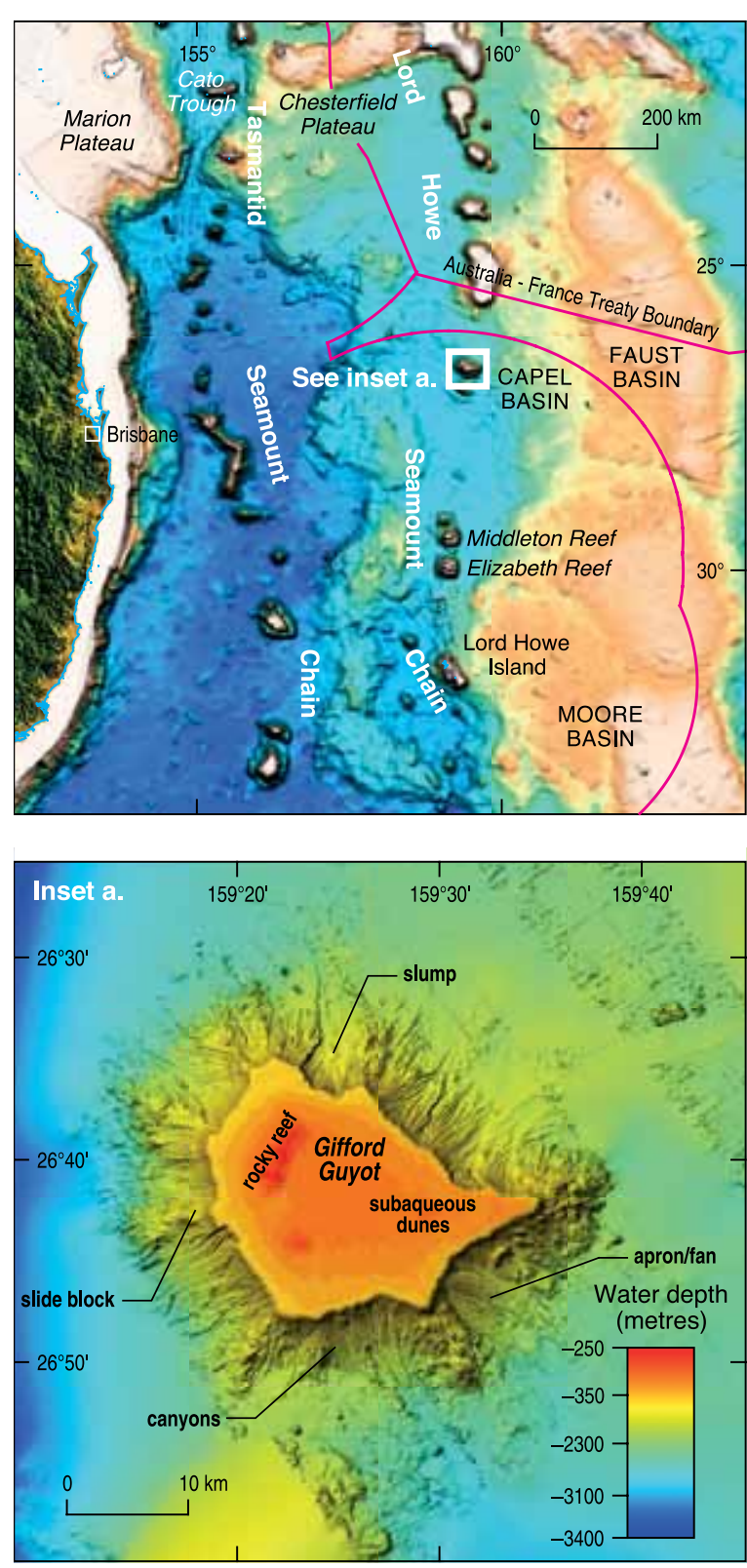

Figure 1.12: Multibeam bathymetry image of the $15.6 \mathrm{Ma}$ Gifford Guyo. The guyot forms part of the Lord Howe Seamount Chain to the east of the Tasmantid Seamount Chain (Figure 2.3) The seamounts are elevated areas of volcanoes generated from mantle hotspots over the northward-moving Australian Plate. The Gifford Guyot has an extensive flat summit ca $200 \mathrm{~m}$ bsl. Guyots have highly variable seabed habitats, making them an important foundation for diverse marine life (Chapter 6).
The relatively small islands of Lord Howe in the Tasman Sea (Figure 1.12), and Heard/McDonald (Box 1.6) in the Southern Ocean, surmount very large mid-ocean plateaus (Frontispiece). These plateaus, which sit above the level of the deep ocean floor, generate large associated continental margins despite the small area of the exposed landmasses.

The presence of numerous marginal plateaus and terraces within the margins of mainland Australia and Tasmania is a distinctive feature of the Australian margin compared with other continents. Many of the plateaus off eastern and southern Australia are underpinned by rifted/ extended continental crust. In contrast, the plateaus off Western Australia are commonly heavily modified by magmatism generated by the breakup of Gondwana (Chapter 4).

Deep ocean-floor provinces occur in water depths of more than $4000 \mathrm{~m}$ adjacent to all margins but are absent in the north and around Norfolk Island, off the eastern mainland. Adjacent to mainland Australia, they are most extensive in the east and south of the jurisdiction, particularly where the slope is steep and narrow. Around the Christmas and Cocos (Keeling) islands, most of the surrounding seafloor is deep ocean floor. Similarly deep ocean floor lies close to Macquarie Island. The $6700 \mathrm{~m}$ deep Hjort Trench lies adjacent to the southwest portion of the $1600 \mathrm{~km}$ long Macquarie Ridge Complex and is the deepest seafloor adjacent to Australian territory (Frontispiece).

Volcanic seamounts and guyots of various sizes are a common aspect of the deep ocean floor. The north-trending Tasmantid Seamount Chain extends along the eastern edge of the north Tasman Basin and Cato Trough off eastern Australia (Figures 1.12 and 2.3). A number of individual seamounts/guyots within this chain rise spectacularly from the relatively flat-lying deep ocean floor of the Tasman Basin at $4500 \mathrm{~m}$ depth to within less than $200 \mathrm{~m}$ of sea-level (Figure 1.12).

\section{Opportunities and responsibilities within Australia's marine jurisdiction}

Australia has sovereign rights for resources across a vast marine jurisdiction. However, many parts of the jurisdiction are remote and poorly known, and lie in water depths of $1000 \mathrm{~m}$ to $4500 \mathrm{~m}$. Previous and current petroleum exploration has mostly occurred in the relatively shallow waters. There are very few areas of Australia's marine jurisdiction that can be regarded as mature for petroleum exploration, and most parts are still underexplored by international standards (Chapter 4).

All of Australia's continental margin sedimentary basins with petroleum potential lie within its newly confirmed marine jurisdiction. The deep-water parts of the continental margin include significant frontier petroleum exploration areas. Many of these areas are poorly surveyed and are generally not included in conventional estimates of undiscovered resources. There are many other parts of Australia's jurisdiction, such as the Macquarie Ridge, that do not have any petroleum but do have considerable significance because of their ecological, environmental and scientific values.

The vast marine jurisdiction also provides opportunities for a range of mineral resources (Appendix 1.2.3). The seabed around Australia is 


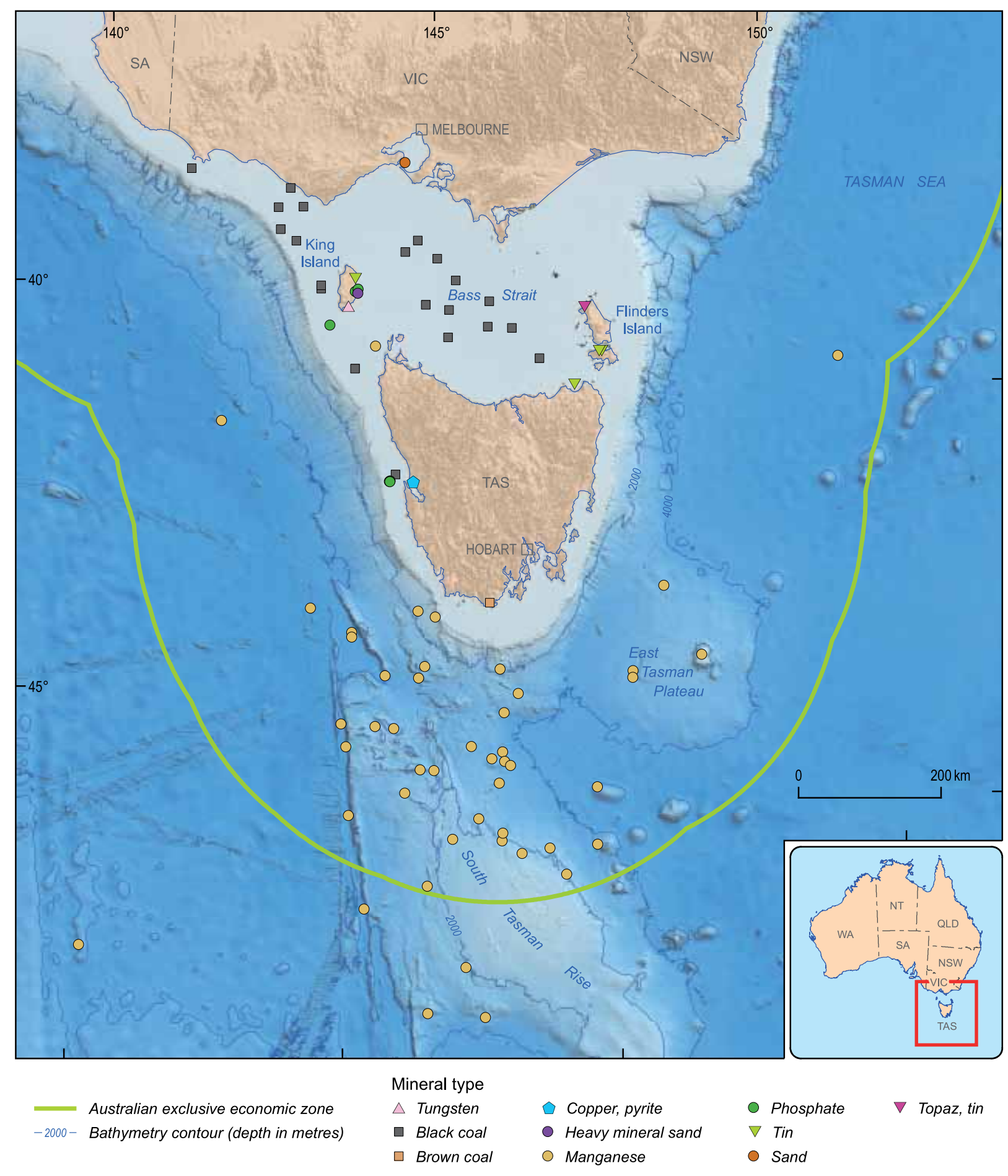

known to host a vast array of economic minerals, including manganese ( $\mathrm{Mn})$, Au, heavy mineral sands, tin (Sn), tungsten (W), Fe and even phosphate. Industrial commodities such as shell sand, sand and aggregate are currently commercially extracted. The seabed around Tasmania has proved rich in a variety of mineral resources (Figure 1.13).

In addition to the rights to explore and exploit the resources of its marine jurisdiction, Australia has the obligation to protect and preserve the marine environment. This is a significant obligation given that parts of the three large oceans (the Pacific, Indian and Southern) and the Tasman, Coral, Arafura and Timor seas cover all five of the world's temperature zones-tropical, subtropical, temperate, subpolar and polar (Figure 1.4). Consequently, Australia's marine environment is home to a wide biodiversity due to the broad range of habitats afforded by latitude, the characteristics throughout the water column (e.g. nutrients, temperature and light), and the geomorphological and geological variability of the seafloor.

Figure 1.13: Extract around the island of Tasmania from the Australian Offshore Minerals Locations Map (Appendix 1.2.3), showing the array of different mineral commodities and their distribution. 
Jupp J (ed.) 2002. The Australian people: an encyclopaedia of the nation, its people and their origins, Angus \& Robertson, Sydney.

Keneally T 2009. Australians: origins to Eureka, Allen \& Unwin, Sydney.

Libby R 2007. How a continent created a nation University of New South Wales Press Ltd, Sydney.

Lynch A, Harbort G \& Nelson M 2010. History of flotation, AusIMM Spectrum Series 18, Australian Institute of Mining and Metallurgy, Carlton.

May SK, Taçon PSC, Wesley D \& Travers M 2010. Painting history: indigenous observations and depictions of the 'Other' in northwestern Arnhem Land, Australia. Australian Archaeology 71, 57-65.

Mulvaney DJ 1969. The prehistory of Australia,

Thames \& Hudson, London.

O'Connor S 2009. Earliest seafaring, AccessScience, McGraw-Hill Companies. www.accessscience.com

O'Connor S \& Chappell J 2002. Colonisation and coastal subsistence in Australia and Papua New Guinea: different timing, different modes. In: Pacific archaeology: assessments and prospects, Sand C (ed.), Les Cahiers de l'Archéologie en Nouvelle-Calédonie, Nouméa, 15-32.

Pope KO \& Terrell JE 2008. Environmental setting of human migrations in the circum-Pacific region. Journal of Biogeography 35, 1-21.

Refugee Council of Australia 2011. Australia's refugee and humanitarian program 2010-11: community views on current challenges and future directions, Refuge Council of Australia submission to the Australian Government.

Rehman I 2011. From down under to top center: Australia, the United States, and this century's special relationship, Transatlantic Academy Paper Series, Transatlantic Academy, Washington.

Rowley CD 1972. The destruction of Aboriginal society, Penguin Books Ltd, Australia.

\section{Australian geology: the shaping influence}

Australian Government Department of Sustainability, Environment, Water, Population and Communities 2011. Six seasons of Kakadu. www.environment.gov.au/parks/

kakadu/nature-science/seasons.htm

Birrell R et al. (eds) 1982. Quarry Australia? Social and environmental perspectives on managing the nation's resources, Oxford University Press, Melbourne.

Bureau of Meteorology 2009. Climate of Australia: the authoritative climate reference, Bureau of Meteorology, Melbourne.

Bureau of Meteorology 2011. Australian climate influences. www.bom.gov.au/watl/about-weather-and-climate/australianclimate-influences.shtml

Garnaut R 2011. The Garnaut Review 2011: Australia in the global response to climate change, Cambridge University Press, Port Melbourne.

Geoscience Australia 2011. Landforms. www.ga.gov.au/ education/geoscience-basics/landforms.html

Mercer D \& Marden P 2006. Ecologically sustainable development in a 'quarry' economy: one step forward, two steps back. Geographical Research 44, 183-203.

National Library of Australia 2007. Australia in maps: great maps in Australia's history from the National Library's collection, National Library of Australia, Canberra.

Nielsen JN 2008. Life and landscape, blog http:// geopolicraticus.wordpress.com/2008/11/08/life-andlandscape

Pike D 1970. Australia: the quiet continent, 2nd edn, Cambridge University Press, Cambridge.

Price AG 1972. Island continent: aspects of the historical geography of Australia and its territories, Angus \& Robertson, Sydney.

Seddon G 1997. Landprints: reflections on place and landscape, Cambridge University Press, Cambridge.

\section{Knowing Australia's limits}

Brown BJ, Müller RD, Gaina C, Struckmeyer HIM, Stagg HMJ \& Symonds PA 2003. Formation and evolution of Australian passive margins: implications for locating the boundary between continental and oceanic crust. In: Evolution and dynamics of the Australian Plate, Hillis RR \& Müller RD (eds), Geological Society of Australia Special Publication 22 and Geological Society of America Special Paper 372, Geological Society of America, Boulder, \& Geological Society of Australia, Sydney, 217-237.

Heap AD \& Harris PT 2008. Geomorphology of the Australian margin and adjacent seafloor. Australian Journal of Earth Sciences 55, 555-585.

Heap AD, Hughes M, Anderson T, Nichol S, Hashimoto T, Daniell J, Przeslawski R, Payne D, Radke L \& Shipboard Party 2009. Seabed environments and subsurface geology of the Capel and Faust basins and Gifford Guyot, eastern Australia, Geoscience Australia Record 2009/22, Geoscience Australia, Canberra.

Kerr A 2009. A federation in these seas: an account of the acquisition by Australia of its external territories, Attorney-General's Department, Canberra.

Symonds PA 2001. Australia’s Southern Ocean jurisdiction and opportunities under the Law of the Sea. In: Looking south - managing technology, opportunities and the global environment, proceedings of the 2001 Invitation Symposium of the Australian Academy of Technological Sciences and Engineering, Hobart, 20-21 November 2001, 162-180

Symonds PA \& Willcox JB 1989. Definition of the continental margin using UN Convention on the Law of the Sea (Article 76), and its application to Australia, Bureau of Mineral Resources record 1988/38, Bureau of Minera Resources, Canberra.

Symonds PA \& Willcox JB 1989. Australia’s petroleum potential in areas beyond an exclusive economic zone. BMR Journal of Australian Geology \& Geophysics 11(1), 11-36. 